\title{
The Corporate Saving Glut in the Aftermath of the Global Financial Crisis
}

Gruber, Joseph W., and Steven B. Kamin

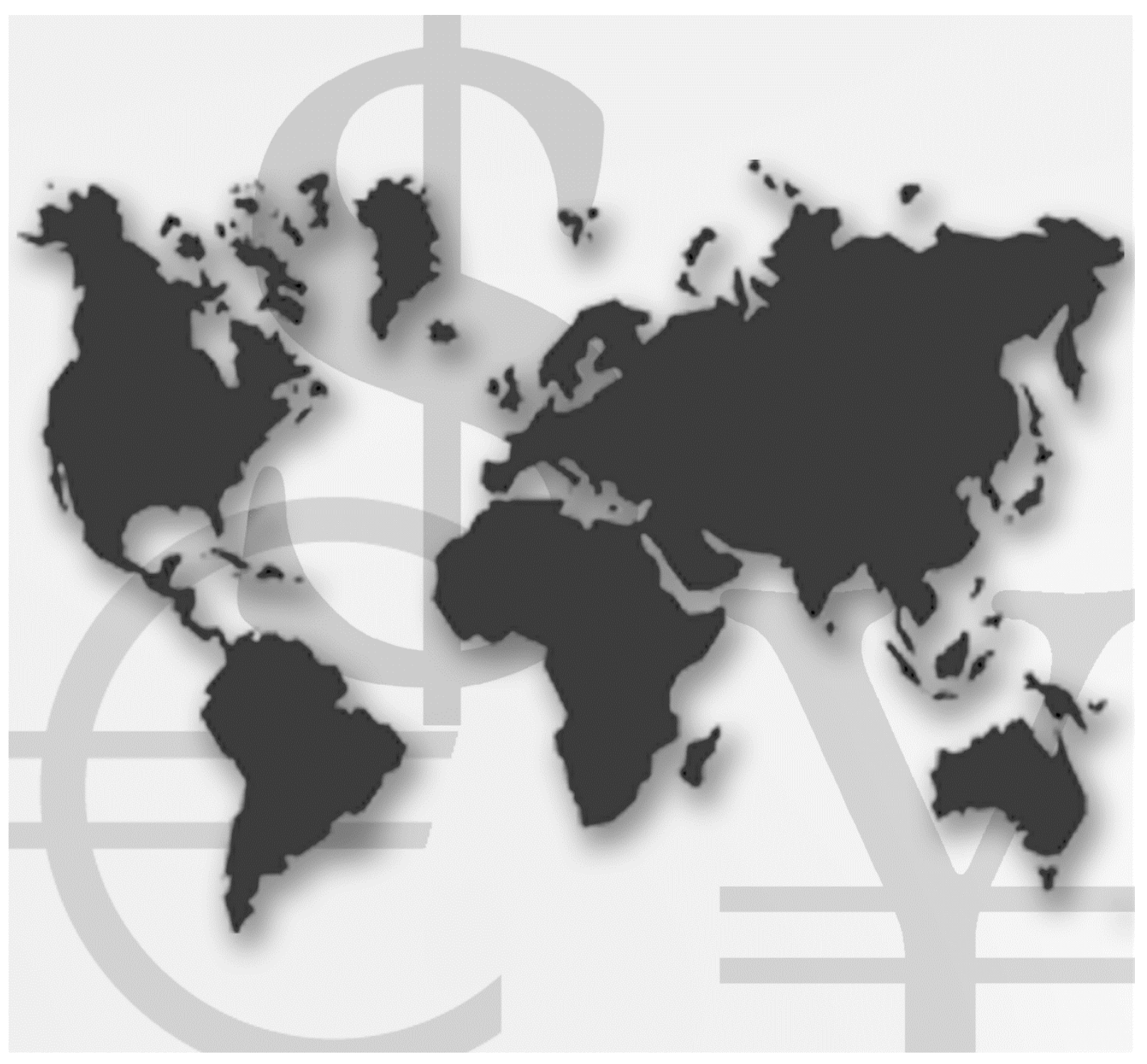

\section{International Finance Discussion Papers}

Board of Governors of the Federal Reserve System

Number 1150

October 2015 


\section{Board of Governors of the Federal Reserve System \\ International Finance Discussion Papers}

Number 1150

November 2015

The Corporate Saving Glut in the Aftermath of the Global Financial Crisis

Joseph W. Gruber and Steven B. Kamin

NOTE: International Finance Discussion Papers are preliminary materials circulated to stimulate discussion and critical comment. References in publications to International Finance Discussion Papers (other than an acknowledgment that the writer has had access to unpublished material) should be cleared with the author or authors. Recent IFDPs are available on the Web at www.federalreserve.gov/pubs/ifdp/. This paper can be downloaded without charge from Social Science Research Network electronic library at http://www.ssrn.com/. 


\title{
The Corporate Saving Glut in the Aftermath of the Global Financial Crisis
}

\author{
Joseph W. Gruber and Steven B. Kamin*
}

\begin{abstract}
We examine the increase in the net lending (saving minus investment) of nonfinancial corporations in the years preceding and especially following the Global Financial Crisis (GFC). We consider whether this increase in net lending is an endogenous reflection of the current weak pace of growth or an outcome of other factors, such as firms' desire to cut investment and hoard assets, and thus an exogenous drag on growth. Looking at G7 economies, we find that the fall in corporate investment during the GFC was in line with historical norms, given the path of GDP growth, interest rates, profits, and other relevant determinants. However, we find that investment declined from a surprisingly weak starting point, as corporate investment in many of the G7 economies started falling below our models' predictions in the years before the GFC. Moreover, corporate payouts to investors in the form of dividends and equity buybacks have trended up over the past $1 \frac{1}{2}$ decades, inconsistent with the view that cautious firms were cutting back on investment spending to strengthen their balance sheets. Identifying the causes of the rise in corporate net lending and declines in investment rates starting in the years before the GFC should be an important focus of future research.
\end{abstract}

Keywords: Investment, Corporate Saving, Corporate Balance Sheets

JEL Classifications: E21, E22, G30

* The authors are Deputy Associate Director and Director of the International Finance Division, Board of Governors of the Federal Reserve System, Washington DC 20551 U.S.A. They can be reached at joseph.w.gruber@frb.gov and steven.kamin@frb.gov. The views in this paper are solely the responsibility of the authors and should not be interpreted as reflecting the views of the Board of Governors of the Federal Reserve System or of any other person associated with the Federal Reserve System. Michael DeDad provided superb research assistance. 


\section{Introduction}

In the years leading up to the global financial crisis (GFC), the current account surpluses of the emerging Asian economies and Middle East oil producers received widespread attention. In a series of influential speeches, Bernanke $(2005,2007)$ argued that these surpluses represented a "global saving glut" that upset the international balance of supply and demand and was imposing downward pressure on interest rates around the world. In recent years, another potential source of leakage from aggregate demand has also come into view. Sometimes labeled the "corporate saving glut" (Loeys et.al., 2005), it represented the excess of saving over investment among the corporations of many of the world's leading economies. This excess did not receive as much attention as the global saving glut, but it could have considerable consequences for economic activity and external imbalances around the world, particularly as it has widened considerably in recent years.

Figure 1 plots the evolution of the corporate saving glut for the United States. Saving (the blue line) is calculated as the undistributed profits of non-financial corporations, that is after-tax profits less dividends to shareholders. Investment (the red line) represents spending by non-financial corporations on capital formation. Any excess of saving over investment represents net lending to the rest of the economy, the black bars at the bottom of the chart. For most of the period before 2000, non-financial corporations borrowed on net from the rest of the economy to finance their investments, as indicated by their negative net lending rates. However, during the years 2002-2005, these corporations experienced small positive net lending positions. These positions then ballooned after the global financial crisis, exceeding 3 percent of GDP for a time. 
Considering the conventional view that the corporate sector borrows from the household sector to finance capital investment, this is a surprising outcome and one that appears to represent a significant leakage from aggregate demand.

In other G7 economies, corporations switched from net borrowing to substantial net lending positions even earlier. Figure 2 shows that in Canada, Japan, and the U.K., corporate net lending has been positive since around 2000, while in Germany net lending flattened out at around the same time before turning positive in recent years. Only in France and Italy has net lending remained negative.

The years following the GFC were associated not only with a surge in net lending by nonfinancial corporations, but also by their increased holdings of cash and other liquid financial assets. Figure 3 depicts the well-known accumulation of such assets by Apple, Microsoft, and some other prominent companies, which has prompted complaints that corporations are "hoarding" cash rather than spending it on investment and job creation. It may well be that this cash hoarding is associated with corporate net lending, either because corporations have increased their saving relative to investment in order to bolster their cash holdings, or merely because corporations are parking their excess saving in liquid assets. It should be cautioned, however, that there is no direct one-to-one relationship between corporate net lending and the accumulation of liquid financial assets. For example, if corporations desired to strengthen their liquidity positions, they could issue long-term liabilities and acquire liquid assets, without any change in their net lending positions. By the same token, if corporations substantially boosted their saving relative to investment but used these extra resources to repay debt, this would show up as a rise in net lending but no change in their cash holdings. 
Accordingly, although the causes and effects of corporate cash accumulation are worthy of exploration, in our research, we would like to focus on the overall allocation of corporate saving between investment and other uses (such as accumulation of financial assets). Net lending is a more fundamental measure of corporate saving and investment than cash holdings, and hence could have even more important implications for aggregate demand and economic activity around the world.

Figures 4 through 7, which are based on data for 26 OECD countries, reinforce our conviction that there is a strong link between corporate net lending and macroeconomic performance. Figure 4 plots the change in net lending against one measure of the shortfall in growth since the GFC: the difference between average real GDP growth and its estimated potential growth rate prior to the GFC. The data suggest that countries with the greatest shortfall in recent growth have tended to experience larger increases in corporate lending. Figure 5 shows that increases in corporate net lending since the GFC are correlated with higher current account balances, suggesting that higher corporate saving has not been offset by lower saving in other sectors of the domestic economy. This is confirmed by Figure 6, which relates changes in net lending by nonfinancial corporations to the analogous concept for households (their gross saving minus investment). It suggests that in countries where corporate net lending has risen since the GFC, households have reinforced this drag on demand through similar adjustments of their own. 
Nevertheless, these figures do not indicate why increases in corporate net lending and a weakening of aggregate demand have coincided in many countries. One possibility is that the rise in net lending simply reflects cutbacks in investment spending in response to the recession and subsequent slow economic growth. In this case, net lending is merely an endogenous residual that has expanded as investment fell relative to profits, and its rise has no implications of its own for aggregate demand. But another possibility is that in reaction to the financial turbulence and disruptions to credit associated with the GFC, corporations actively sought to boost net lending in order to accumulate financial assets and bolster their balance sheets. If corporate caution of this sort has been important, it could have led to weaker investment than one might normally expect, given the evolution of macroeconomic conditions since the GFC, and might help to explain the weakness of the global economic recovery. ${ }^{1}$ Criticisms that corporations are holding back the recovery by building cash rather than investing appear to be based on this type of consideration.

Finally, it is possible that corporate net lending has increased not because of caution per se, but simply because firms do not perceive suitable investment opportunities, even with interest rates being extremely low and growth rates of GDP back near more normal levels (at least in the United States and United Kingdom). This possibility recalls concerns about secular stagnation, implying that investment may represent a drag on aggregate demand for a protracted period, as discussed in Summers (2014).

\footnotetext{
${ }^{1}$ Additionally, corporate caution and the desire to hoard cash and other assets, by inducing a cutback in dividends and equity buybacks, could reduce the flow of cash to shareholders and thus depress consumption. However, this effect would be more tenuous, as shareholders might see through the "corporate veil" and take into account the rising value of their equity claims.
} 
The plan of this paper is as follows. Section II outlines the empirical approach of the paper and provides a summary of our main findings. Section III then briefly surveys the limited literature on the corporate saving glut. Section IV reviews the accounting definitions we used to decompose the allocation of profits into investment, paybacks, and balance sheet adjustments. Section V describes our econometric equations and estimation results, while Section VI examines the out-of-sample forecasts of these equations. Section VII concludes.

\section{Empirical Approach and Summary of Results}

In this paper, we seek to evaluate the available evidence to distinguish among the three hypotheses for the increase in corporate saving presented at the end of the previous section. To do so, we find it informative to rearrange the components of corporate net lending. Recall that net lending is defined:

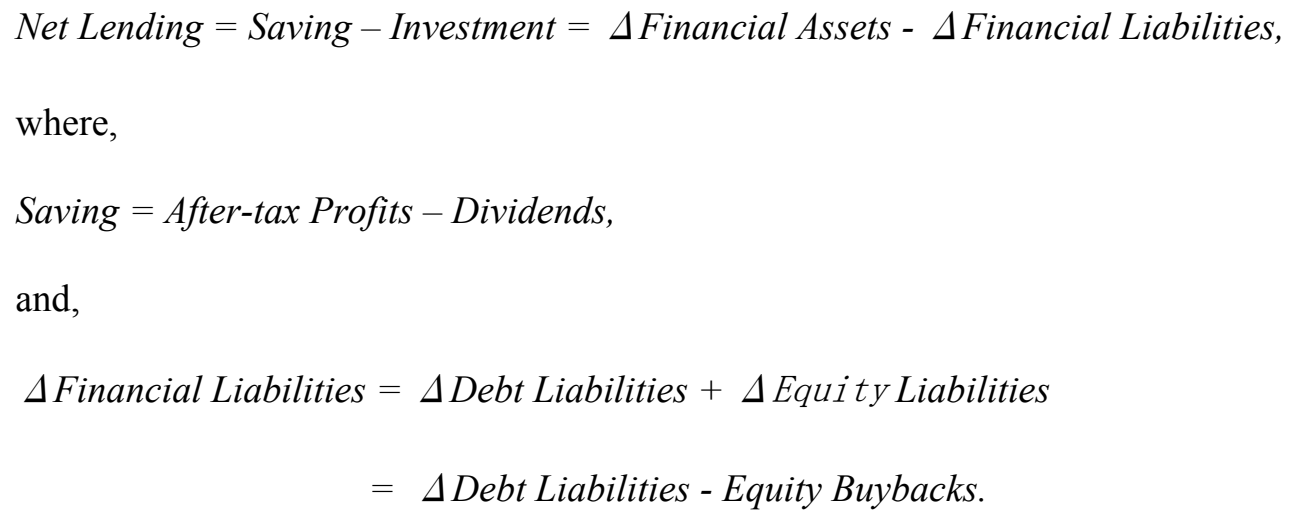

We rearrange the net lending identity to focus on the firm's decision to allocate profits across various uses (see section III for details):

Profits $=$ Investment $+($ Dividends + Equity Buybacks $)+(\Delta$ Financial Assets $-\Delta$ Debt Liabilities $)$ where we define, Payouts $=$ Dividends + Equity Buybacks, and, 
$\Delta$ Net Financial Assets $=\Delta$ Financial Assets $-\Delta$ Debt Liabilities,

such that,

Profits $=$ Investment + Payouts $+\Delta$ Net Financial Assets.

Thus, corporations must choose how to allocate their profits among investment, paying shareholders through dividends or equity buybacks, and adjusting their balance sheets. ${ }^{2}$ As can be seen in Figure 7 for the U.S, our profit allocation approach reveals a distinct step down in investment's share of profits in recent years, with a concurrent increase in the share of profit going to payouts and into financial assets (although both of these shares are quite volatile). Figure 8 presents analogous data for the other G7 economies.

With these definitions established, we evaluate whether the shift in the allocation of corporate profits over the previous decade principally reflected the typical reaction of investment and profits to macroeconomic developments—notably weak economic activity and exceptionally low interest rates_-or whether the shortfalls in investment spending and increases in payouts to investors and asset accumulation may have been unusual relative to their standard determinants. To make this evaluation, we both look in depth at the United States, which has the greatest data availability, and also look at crosscountry data at the aggregate national level. This approach differs from that adopted by the relatively few previous studies of the corporate saving glut, which have focused

\footnotetext{
${ }^{2}$ Juach (2012) and others argue that from an economic (if not tax) perspective, dividends and equity buybacks are nearly identical means of returning resources to shareholders. Therefore a change in preference for buybacks relative to dividends would somewhat arbitrarily increase measured corporate net lending, as buybacks are included in corporate saving and dividends are not. Grouping dividends and buybacks into "payouts" avoids this arbitrary distinction.
} 
primarily on the causes of corporate cash accumulation and draw on data at the firm level to explain this behavior.

Focusing on G7 countries for which adequate flow-of-funds and macroeconomic data are available, we estimate econometric equations linking our three variables of interest — investment, payouts (dividends + equity buybacks), and the adjustment of balance sheets - to an array of standard macroeconomic indicators, including real GDP growth, interest rates, the relative price of capital goods, and profitability. (We examine our variables of interest both as ratios to GDP and as a share of profits, in order to directly address the corporate sector's allocation decision.) These equations are estimated up until 2006, and then are used to forecast the paths of investment, payouts, and net financial accumulation during the period 2007-2013. We then compare the actual paths of these variables to their predicted paths to assess whether they were exhibiting normal responses to the macroeconomic disruptions of the past several years, or whether any unusual pattern of behavior has become apparent.

Of course, in several economies, the rise in corporate net lending and, related, decline in the share of investment in profits was apparent even before the GFC, and may reflect longer-term developments. To evaluate this possibility, we also estimate our econometric equations through 2001 and then compare their out-of-sample forecasts for 2002-2013 with actual developments.

The main findings of our research are as follows. First, reiterating the points made above, in most of the G7 economies we studied, the net lending of nonfinancial corporations rose to very high levels in recent years, and this rise started even before the GFC. The increases were associated with declining shares of both GDP and corporate 
profits allocated to investment. Second, consistent with other studies of recent investment behavior, we found that models estimated up through 2006 generally tracked the weakness of actual investment during the GFC and its aftermath; conversely, models estimated up through 2001 often overpredicted investment in subsequent years, both before and after the GFC. We interpret these results as suggesting that investment in the major advanced economies has indeed weakened relative to what standard determinants would suggest, but that this process started well in advance of the GFC itself. Finally, we find that the counterpart of declines in resources devoted to investment has been rises in payouts to investors in the form of dividends and equity buybacks (often to a greater extent than predicted by models estimated through earlier periods), and, to a lesser extent, heightened net accumulation of financial assets. The strength of investor payouts suggests that increased risk aversion and a precautionary demand for financial buffers has not been the primary reason firms have cut back investment. Rather, our results are consistent with views that, for any number of reasons, there has been a decline in what firms perceive to be the availability of profitable investment opportunities.

\section{Literature Review}

In contrast to the dynamics of aggregate investment, the corporate saving glut directly has not garnered a very long literature, in part because, as discussed above, it only emerged in the mid-2000s and became especially prominent after the GFC in 200708. One of the first mentions of the phenomenon appears in Loeys et.al. (2005), which noted the rise in corporate saving relative to investment around the world, especially in the advanced economies, and attributed the rise to a desire to restructure corporate balance sheets in response to earlier excesses, including equity market bubbles. This 
theme was taken up by the Economist (2005), and also attributed, particularly in Japan, to the desire to reduce debt and strengthen balance sheets. The IMF (2006) attributed the increase in corporate net lending in the 2000s to a number of factors, including declines in interest rates and taxes that improved profitability, declines in the relative price of capital goods that lowered investment spending, and the increased importance of passing profits to shareholders through equity buybacks (which do not reduce measured corporate saving) rather than dividend payments (which do reduce this saving). Andre et.al. (2007) identified many of the same factors as the IMF (2006) paper, and also cited the importance of the cyclical downturn in the early 2000 s as a factor weighing on investment and boosting net lending.

Both IMF (2006) and Andre et.al. (2007) predicted that corporate net lending would likely decline as economic growth strengthened and the process of balance-sheet restructuring was completed. In the event, as described above, the corporate saving glut returned with a vengeance after the GFC. A number of subsequent papers further examined the causes of this glut, although taking a longer view of the process rather than focusing on the GFC and its aftermath. Karabarbounis and Nieman (2012) develop a general equilibrium model to show declines in the price of investment goods could have led to increases in corporate saving relative to investment. Armenter and Hnatkovska (2012) also develop a general equilibrium model to explain the emergence of net lending by the corporate sector. This model focuses on the precautionary motive of firms seeking to accumulate financial assets in order to avoid being financially constrained in the future. 
The precautionary motive of corporations plays an important role in researchers' explanation of a phenomenon that, as noted above, is related to but not the same as the rise in corporate net lending: the rise in corporate cash hoardings. Bates, Kahle, and Stultz (2006) attribute these cash hoardings to increases in volatility and uncertainty about earnings that motivates precautionary saving, as does IMF (2006) and Sanchez and Yurdagul (2013). Falato, Kadyrzhanova, and Sim (2012) argue that as intangible capital (such as technology) has grown as a fraction of total non-financial capital holdings of firms, this reduces the firms' access to collateral for borrowing and leads them to hold greater cash reserves. Finally, many observers have noted that tax laws encourage the holding of cash overseas, although this does not explain the emergence of the corporate saving glut in countries outside the United States. (Sanchez and Yurdagul, 2013)

While studies of recent developments in corporate net lending (and corporate saving) are relatively sparse, the dynamics of aggregate investment is examined by an abundant literature, including a number of papers particularly focused on investment post-GFC. Studies of the post-GFC drop in investment generally fall into one of two camps, those that argue that the fall in investment is in line with the typical cyclical pattern of investment and those that attribute an additional drag from particularly high levels of uncertainty (either economic or policy-related). Among those of the first ilk is IMF (2015) and Pinto and Tevlin (2014), which find that post-GFC investment in the U.S. and other advanced economies is well explained by a simple accelerator model, and Kothari, Lewellen, and Warner (2013), which finds that all the decline in U.S. corporate investment during the crisis can be explained by the change in GDP and profits. Among 
those studies attributing a greater role to uncertainty are Lewis et al (2014) and Banerjee, Kearns, and Lombardi (2015).

\section{Defining Corporate Net Lending and the Allocation of Profits}

In order to clarify the definition of some of the key variables used in our study, and to illustrate the accounting relationships linking them, Table 1 describes the construction of non-financial corporate saving, investment, and net lending as drawn from the U.S.

Integrated Macroeconomic Accounts. These definitions are also reprised in equation (1) below:

Gross Saving $=$ Gross Operating Surplus - Net Interest - Taxes, Rent \& Other

- Dividends $=$ After-tax Profits - Net Dividends

Gross Investment $=$ Investment in Non-financial Assets (Capital Formation)

Net Lending $=$ Gross Saving - Gross Investment

Note that because Net Lending (line 11 on the table) equals the excess of corporations' earnings (net of dividends) over how much they spend on capital formation, it must also equal the net acquisition of financial assets (or net lending as determined by the Financial Account, line 12). The net acquisition of financial assets, in turn, equals the acquisition of financial assets (line 13) minus the accumulation of liabilities (line 14):

Net Lending $=$ Acquisition of Financial Assets - Accumulation of Liabilities $=$ Acquisition of Financial Assets - Accumulation of Debt Liabilities - Accumulation of Equity Liabilities

The table is consistent with the annual data shown in Figure 1. Note that, looking at the Financial Account, net lending as constructed from the acquisition of financial assets minus accumulation of liabilities does not equal net lending as determined by the difference between gross saving and gross capital formation — as in many accounts, there 
are sizeable statistical discrepancies. For the analysis in the paper we reference net lending as derived from the non-financial account, that is, net lending as constructed from the earnings and expenditures data.

As discussed in the introduction, in order to evaluate changes over time in the nexus between corporate profits, investment, and balance sheets, we want to focus specifically on corporations' decisions as to how to allocate their profits. This approach implicitly takes profits as given, as it is beyond the scope of this paper to explain their variation. In principle, we could rewrite equation (1c) above to show how corporations allocate their saving between investment and net lending, as in equation (2) below:

Gross Saving $=$ After-tax Profits - Net Dividends $=$ Gross Investment + Net Lending

However, note that gross saving equals after-tax profits less dividends. Although dividends are a return to capital, the amount of dividends paid by the corporation is usually quite discretionary. Accordingly, as shown in equation (3), it may be more accurate to portray the firm's decision as how to allocate a pre-determined amount of profits (dropping the "after-tax") between dividends, investment, and net lending:

Profits $=$ Net Dividends + Gross Investment + Net Lending (3)

Finally, note in Table 1 that the accumulation of equity liabilities has been negative, on average, for decades (line 14). That is, equity liabilities outstanding have been declining as equity buybacks have exceeded the issuance of new equities. Observers have noted that whereas dividends appear "above the line" as a payment for equity capital (line 8), buybacks appear "below the line" as an asset transaction (exchange of cash for 
reduced equity claims). As argued by Juach (2012) and others, however, in practice dividends and equity buybacks are merely alternative — and economically equivalent— means by which corporations return earnings to shareholders. Accordingly, in considering the profit allocation decision of the firm, it makes sense to include equity buybacks along with dividends as a sum of resources that the firm can return to shareholders. This means that the resultant adjustment of the balance sheet will not be net lending per se (the change in total financial assets minus the change in total liabilities) but what we can call $\Delta$ Net Financial Assets (the change in total financial assets minus the change in debt liabilities): ${ }^{3}$

Profits $=$ Investment $+($ Dividends + Equity Buybacks $)+(\Delta$ Financial Assets $-\Delta$ Debt Liabilities $)$

$$
=\text { Investment }+ \text { Payouts }+\Delta \text { Net Financial Assets }
$$

This is the equation that appears in the introduction.

\section{Estimation of Equations for Allocation of Corporate Profits}

In this section, we estimate simple empirical models of the allocation of corporate profits into their possible uses - investment, payouts (dividends plus equity buybacks), and $\Delta$ Net Financial Assets - in order to assess how unusual recent changes in these allocations have been and what shocks might have accounted for them. We focus on the G6 countries (United States, France, Germany, Italy, Japan, and the United Kingdom) for which the relevant data for the aggregate of non-financial corporations is available.

\section{IV.1 Empirical Methodology}

\footnotetext{
${ }^{3}$ In this formulation, equity buybacks refers more generally to any actions that change the net amount of equity liabilities. For example, $\$ 100$ dollars in equity buybacks lowers equity liabilities by $\$ 100$. Thus, Equity Buybacks $=-\Delta$ Equity Liabilities.
} 
In our empirical research, we estimate regressions using annual data from the non-financial corporate sectors of the G6 countries listed above for three separate dependent variables: investment, payouts (dividends plus equity buybacks), and $\Delta \mathrm{Net}$ Financial Assets (change in financial assets minus change in debt liabilities). (Data for most of the non-G6 countries is not available in sufficiently long time series.) All of the variables are expressed in nominal terms in their respective currencies, and (in separate equations) they are scaled by nominal GDP and by profits.

Precise definitions and data sources for the explanatory variables are provided in Appendix A. The explanatory variables include standard macroeconomic factors that would be expected to affect the allocation of corporate profits toward investment and other uses, albeit in different ways: GDP growth, the real interest rate (defined as the 10year rate minus contemporaneous inflation), and the growth of profits. We also include a number of measures that might be especially relevant to trends in investment spending, including the relative price of capital formation (the ratio of the fixed investment deflator to the GDP deflator) and the share of intangible investment in total investment. (Researchers have suggested that the increasing importance of intangible investment, such as development of computer software, may have diminished the amount of collateral that firms can use to secure loans, and thus reduced investment spending and boosted corporate saving. $)^{4}$ Most of the explanatory variables were lagged one year in order to reduce the likelihood of their coefficients being contaminated by endogeneity with respect to the dependent variables.

\footnotetext{
${ }^{4}$ We also experimented with several measures of uncertainty - within-year revisions of expected profits from the Consensus Forecasts, the Baker, Bloom, and David (2013) index of policy uncertainty - but these proved not to be consistent explainers of our dependent variables, and thus results with these terms are not included in this draft.
} 
The equations were estimated in two ways: First, for every dependent variable, we estimated a separate time-series regression for the United States, taking advantage of the exceptionally long data series that are available. Second, we estimated panel regressions pooling data for all six G6 countries. In our panel regressions, we also include countryspecific fixed-effect dummy variables in order to account for idiosyncratic differences in corporate saving and investment behavior across countries that are unlikely to be explained by our macroeconomic variables. ${ }^{5}$

Finally, all regressions were estimated through three end-points: 2001, 2006, and 2013. The estimation results for the two shorter periods are used to compute out-ofsample predictions, to be described in Section VI.

\section{IV.2 Estimation Results}

Tables 2 through 5 summarize our estimation results. Each table presents equation estimates for the three dependent variables (investment, payouts, and $\Delta \mathrm{Net}$ Financial Assets) for a particular estimated time-range.

Table 2a-c (U.S. data only, dependent variables as share of GDP): The equations in Table 2a are estimated for the period 1961-2001. Starting with the equation for investment/GDP, most explanatory variables have coefficients that are statistically significant and of the expected sign: higher growth of GDP and profits raises investment, while higher real interest rates and shares of investment devoted to intangibles lowers investment. In principle, the coefficient on the relative price of investment goods could have either sign, depending on the price elasticity of demand for investment goods; in practice, the coefficient is close to zero and statistically insignificant.

\footnotetext{
${ }^{5}$ We also included a dummy variable for the UK in 1999 and 2000 in the panel regressions for payouts and $\Delta$ Net Financial Assets, in order to control for some especially large outliers in these series.
} 
The equations for payouts and $\Delta$ Net Financial Assets have lower R2's and larger standard errors. Higher real interest rates appear to boost payouts, as does profit growth, albeit not very significantly. Higher shares of investment devoted to intangibles boosts $\Delta$ Net Financial Assets, perhaps because firms are forced to self-finance a larger portion of intangible investment given that it is more difficult to collateralize; balance sheets also benefit from higher profit growth and lower GDP growth, with the latter effect possibly reflecting that during periods of high growth, firms borrow to invest and thus run down their net financial asset position.

Tables $2 \mathrm{~b}$ and $2 \mathrm{c}$ present estimates of the same equations estimated over the 1961-2006 and 1961-2013 periods, respectively. Compared to the estimates in Table 2a, there are some differences in the value and statistical significance of the coefficients, but it is difficult to assess the overall implication of these differences for changes in behavior. Comparison of the out-of-sample forecasts of these equations, to be discussed in Section V below, will be more informative.

Tables 3a-c (U.S. data only, dependent variables as share of after-tax profits): These tables follow along the same lines as Tables 2a-c, except that the dependent variables are expressed as shares of after-tax profits rather than of GDP. Because the three shares of profits (investment, payouts, and $\Delta$ Net Financial Assets) sum to unity, the equations are linearly dependent, such that any one equation is the residual of the other two and, as long as the three equations have the same explanatory variables, the coefficients on each independent variable sum to zero across the three equations. We show all three equations in order to allow us to see exactly how shocks alter the corporate allocation of profits between their three uses. We ensure that the three equations have exactly the same 
explanatory variables by including the same two lagged dependent variables in each equation, investment/profits and payouts/profits. (Adding the lag of $\Delta$ Net Financial Assets would not be possible, as the three lags would be perfectly collinear.)

Starting with the investment equation, only real GDP growth is a consistent significant explainer of the investment/profits ratio across the three time ranges shown in Tables $3 \mathrm{a}, \mathrm{b}$, and $\mathrm{c}$. Conversely, for the payouts/profits ratio, it is generally the case across all three tables that higher real interest rates significantly boost payouts (as was also the case for the payouts/GDP ratio in Table 2), while higher relative investment prices, intangibles shares in investment, and profits growth all depress payouts/profits. Finally, these explanatory variables generally take the opposite sign for the $\Delta$ Net Financial Assets/Profits equations, with real GDP growth generally lowering net financial asset accumulation while the proportion of intangibles investment and profit growth raises it.

Tables 4a-c (G6 panel regression, dependent variables as share of GDP): These equations are specified nearly exactly like those for the U.S. data alone, except that we have added another explanatory variable that may be expected to vary substantially across countries: the share of the population over age 65. As in the U.S.-only regressions, the only consistent significant explainers of investment across all three estimation periods are the real GDP growth rate and the share of intangibles in investment. There are no consistent significant explainers of the payouts/GDP ratio. And as in the U.S.-only specifications, $\Delta$ Net Financial Assets consistently and significantly decline in response to real GDP growth and rises with profit growth; in the two longer estimation samples, a higher share of over-65 in the population also boosts financial asset accumulation. 
Tables 5a-c (G6 panel regression, dependent variables as share of after-tax profits):

All told, these equations estimates do not differ greatly from their predecessors. Real

GDP growth is the principal significant explainer of investment, though the over-65 share

of the population is important in two of the estimation periods. Payouts show no

consistent response to the explanatory variables. Net financial asset accumulation

responds negatively to real GDP growth.

\section{Out-of-sample Forecasts}

Based on the estimated equations described above, we now compare actual developments in corporate investment, payouts, and net financial asset accumulation to their forecasted paths. These forecasts are based on dynamic simulations of the model: the model prediction for the dependent variable in time $t$ is used for the lagged dependent variable in the prediction for time $t+1{ }^{6}$ The forecasts are computed for all the variants of the equations described above: the time-series estimates using only U.S. data as well as the G6 panel data; the dependent variables expressed as a share of GDP and expressed as a share of profits. Finally, the out-of-sample forecasts are computed using two jumpingoff points: 2002 (based on equations estimated through 2001) and 2007 (based on equations estimated through 2006).

Investment equations: Figure 9 presents out-of-sample forecasts for investment/GDP, based on time-series estimation using U.S. data along; the red dashed line indicates the forecast starting in 2002 and the blue dashed line indicates the forecast starting in 2007. The red and blue dotted lines indicate width of the 2-standard-error bands spanning these

\footnotetext{
${ }^{6}$ For forecasts of the models where the dependent variables are expressed as shares of profits, so that two lagged dependent variables are included in each equation, the three equations are simulated jointly so that the forecasted values of the profit shares feed into the right-hand side of the other equations in which they appear.
} 
forecasts. Notably, the latter forecast tracks investment during the GFC relatively well. This result, similar to that found by Pinto and Tevlin (2014) and others, suggests that there was nothing extraordinary about the GFC in terms of its effect on investment: investment retained its prior relationship with its forcing variables.

However, the forecast path that jumps off from 2002 is consistently above its subsequent actual path; the bottom of the confidence interval just barely encompasses the actual path. This suggests that while the GFC per se may not have unduly weakened investment, investment may have been on a downward swing — relative to its standard determinants - even before the GFC, consistent with its actual decline over the period since 2000 .

Figure 10 focuses on investment/profits, also based on the time-series estimation using U.S. data alone. The message is quite similar to that from the previous chart: Based on the forecasts jumping off of 2006, predicted investment/profts is actually below the actual path. Conversely, jumping off from 2002, the model predicts a much more gradual path of decline that actually took place.

Figure 11 switches back to investment/GDP, but is based on estimation of the panel regression for the G6 countries. (We drop the standard error bands for the panel results owing to lack of space; in general, these error bands are quite wide, and forecast results should be viewed as suggestive rather than determinative.) Focusing on the forecasts starting in 2007 , there is no clear evidence of a surprising shortfall in investment: For the United States and France, investment generally exceeded forecasts; for Japan and Italy, actual and predicted investment were similar; only for the United Kingdom and Germany did actual investment fall well short of predicted. By contrast, 
jumping off of 2002, investment/GDP falls strikingly below predicted for the United Kingdom and consistently below for the United States, France, and Germany.

Finally, Figure 12 shows results from the G6 panel regression for investment/profits. Again, the forecasts jumping off from 2006 generally track actual investment/profits reasonably well or even underpredict during the GFC and afterwards. Conversely, the forecasts jumping off from 2002 substantially and consistent overpredict investment/profits in the United State, United Kingdom, and France.

Payouts equations: As might be expected, the behavior of payouts—dividends plus equity buybacks - in recent years is the flip side of the behavior of investment. Figure 13 compares actual and predicted payouts/GDP, based on the U.S. data time-series regressions. Jumping off from the very elevated level of payouts in 2006, predicted payouts generally exceed actual (albeit not by a statistically significant extent). Conversely, the forecast that starts in 2002, not surprisingly, missed the huge spike in payouts in 2006-07 and the second, smaller spike in 2011-12. Thus, regardless of which caused which, some of the shortfall in investment spending since 2001 appears to be mirrored in heightened payouts. A similar result holds for the payouts/profits variable shown in Figure 14.

The forecast results from the panel regressions, shown in Figures 15 and 16, follow the general pattern described above, albeit loosely. For France, Germany, the United Kingdom, and the United States, forecasts jumping off of 2006 come closer to predicting the high level of subsequent payouts than forecasts jumping off of 2001, although this may in part reflect the higher jumping-off point of the later forecasts. 
The rise in payouts in the past decade in most of these countries, and to a greater extent that predicted by our models, not only provides some sense of what corporations did with the resources they didn't apply to investment. It also provides some evidence against one theory of why investment has been so weak in the past decade, as referenced in the introduction: that financial turbulence and cutoffs of credit led firms to cut back investment in order to build "war chests" of financial assets. If that were the case, presumably firms would have cut back on their payouts to build up their balance sheets, but in fact, payouts rose to new highs.

Balance sheet accumulation: Figures 17 and 18 show our forecasts for the change in net financial assets (financial assets minus debt liabilities) as a share of GDP and profits, respectively. For both variants of this measure, and for both the forecasts jumping off from 2001 and those jumping off from 2006, there is some evidence that by the end of the forecast period, actual net asset accumulation has exceeded the forecasts (albeit not by a statistically significant amount). The evidence for other countries, based on forecasts from the panel regressions shown in Figures 19 and 20, is too mixed to characterize easily.

\section{Conclusion}

In this paper, we have demonstrated that both before but especially after the global financial crisis (GFC), levels of corporate net lending — saving minus investment—rose significantly in many economies, raising questions about why this increase took place and what were its implications for the pace of economic recovery. Focusing on aggregate macroeconomic and flow-of-funds data, our research suggests that the increased prominence of the corporate saving glut—or, related, the especially sharp declines in 
corporate investment as shares of profits and GDP—since 2007 was probably an endogenous response to the macroeconomic disruptions associated with the GFC rather than an independent factor contributing to those disruptions. However, we also found that in the half-decade before the GFC, corporate investment rates had fallen below levels that would have been predicted by models estimated in earlier years.

Moreover, this weakness in investment spending does not appear to reflect corporate caution in response to either the dot-com bust or subsequence GFC, as some observers have hypothesized. Corporate payouts to investors, in the form of dividends and equity buybacks, have generally trended up since the early 2000 s and remained strong even after the GFC; such behavior seems inconsistent with a desire by corporations to cut back spending to rebuild balance sheets.

These considerations suggest that the emergence of the corporate saving glut may be more related to a perceived paucity of profitable investment opportunities than to a tightening of financial conditions or surge in corporate caution. Such a development appears consistent with the concerns about secular stagnation that have gained attention of late. (See Summers 2014) But what is causing this paucity of investment opportunities, and what are its implications for future investment and growth, must be the subjects of future research. 


\section{REFERENCES}

André, C. et al. (2007), “Corporate Net Lending: A Review of Recent Trends", OECD Economics Department Working Papers, No. 583.

Armenter, Roc and Viktoria Hnatkovska (2012), “The Macroeconomics of Firms' Saving," working paper, August.

Baker, Scott R., Nicholas Bloom, and Steven J. David (2013), "Measuring Economic Policy Uncertainty" Working paper. Data retrieved from www.policyuncertainty.com.

Banerjee, Ryan, Jonathan Kearns, and Macro Lombardi (2015), “(Why) is investment weak?" BIS Quarterly Review, March

Bates, Thomas W., Kathleen M. Kahle, and Rene M. Stulz (2006), "Why Do U.S. Firms Hold So Much More Cash Than They Used To?” NBER Working Paper No. 12534.

Bernanke, Ben S. (2005), "The Global Saving Glut and the U.S. Current Account Deficit." The Sandburg Lecture, Virginia Association of Economists, Richmond, VA, March 10.

Bernanke, Ben S. (2007), "Global Imbalances: Recent Developments and Prospects." The Bundesbank Lecture, Berlin, Germany, September 11.

Chinn, Menzie and E. Prasad (2003), "Medium-Term Determinants of Current Accounts in Industrial and Developing Countries: An Empirical Exploration," Journal of International Economics 59, 47-76.

The Economist (2005), “The Corporate Saving Glut,” July 7.

Falato, Antonio, Dalida Kadyrhanova, and Jae W. Sim (2012). "Rising Intangible Capital, Shrinking Debt Capacity, and the US Corporate Savings Glut," working paper, June.

Gruber, Joseph and S. Kamin (2007), "Explaining the Global Pattern of Current Account Imbalances," Journal of International Money and Finance 26, 500-522.

International Monetary Fund. 2006. "Awash with cash: Why are corporate savings so high." World Economic Outlook.

International Monetary Fund (2015), "Private Investment: What's the hold up?" World Economic Outlook April.

Jauch, Sebastian (2012), “The Global Savings Glut, Corporate Savings and the Role of Share Repurchases," Ludwig-Maximilians Universitat, working paper, April. 
Karabarbounis, Loukas and Neiman, Brent (2012), "Declining Labor Shares and the Global Rise of Corporate Saving (2012),” NBER Working Paper No. 18154.

Kothari, S.P., Jonathan Lewellen, and Jerold B. Warner (2013), "The Behavior of Aggregate Corporate Investment” Working Paper.

Lane, Philip R. and Gian Maria Milesi-Ferretti (2011), "External Adjustment and the Global Crisis,” IMF Working Paper WP/11/197, August.

Lewis, Christine, Nigel Pain, Jan Strasky, and Fusako Menkyna (2014), "Investment Gaps after the Crisis" OECD Economics Department Working Papers, No. 1168.

Loeys, Jan et.al. (2005), “Corporates are driving the global saving glut,” JP Morgan Research, June 24.

Pinto, Eugenio, and Stacey Tevlin (2014) "Perspectives on the Recent Weakness in Investment” FEDS Note, May 21, 2014.

Sanchez, Juan M. and Emircan Yurdagul (2013), "Why Are Corporations Holding So Much Cash?” The Regional Economist, Federal Reserve Bank of St. Louis, January.

Summers, Lawrence (2014), "U.S. Economic Prospects: Secular Stagnation, Hysteresis, and the Zero Lower Bound" Business Economics Vol. 49, No. 2. 
Figure 1

\section{United States - Non-Financial Corporations}

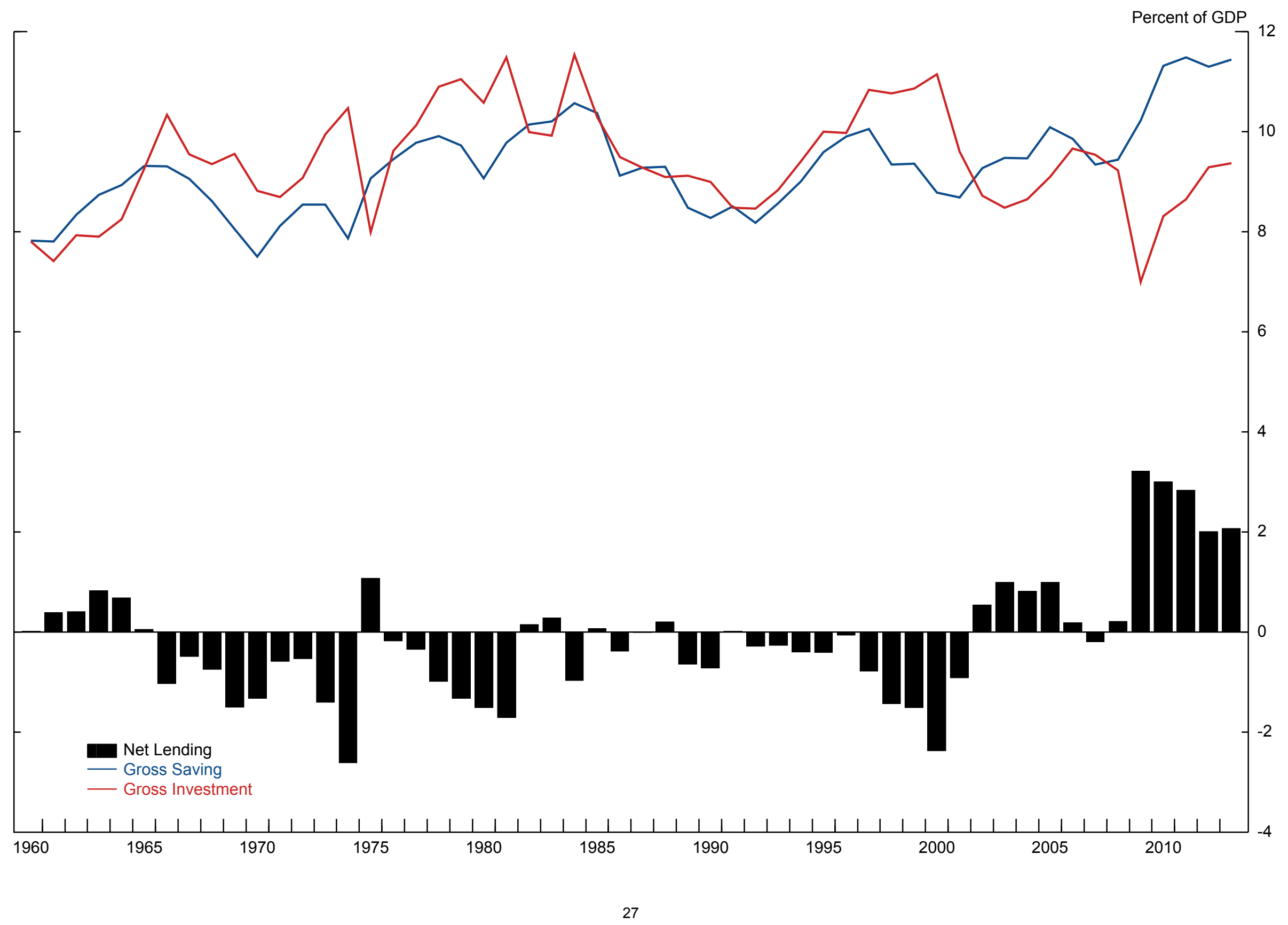


Figure 2

\section{G-7 Net Lending}

1. Japan - Non-Financial Corporations

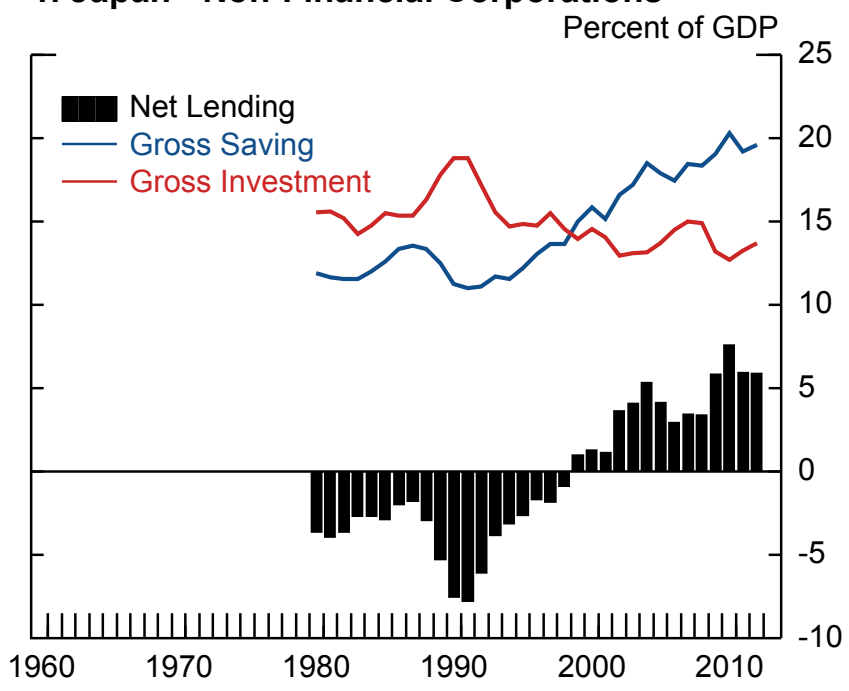

3. U.K. - Non-Financial Corporations

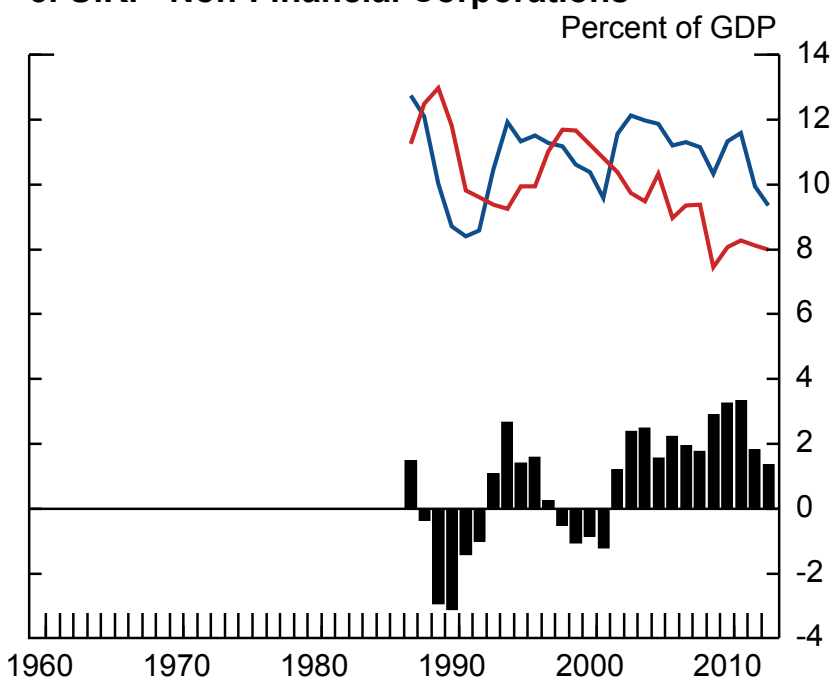

5. France - Non-Financial Corporations

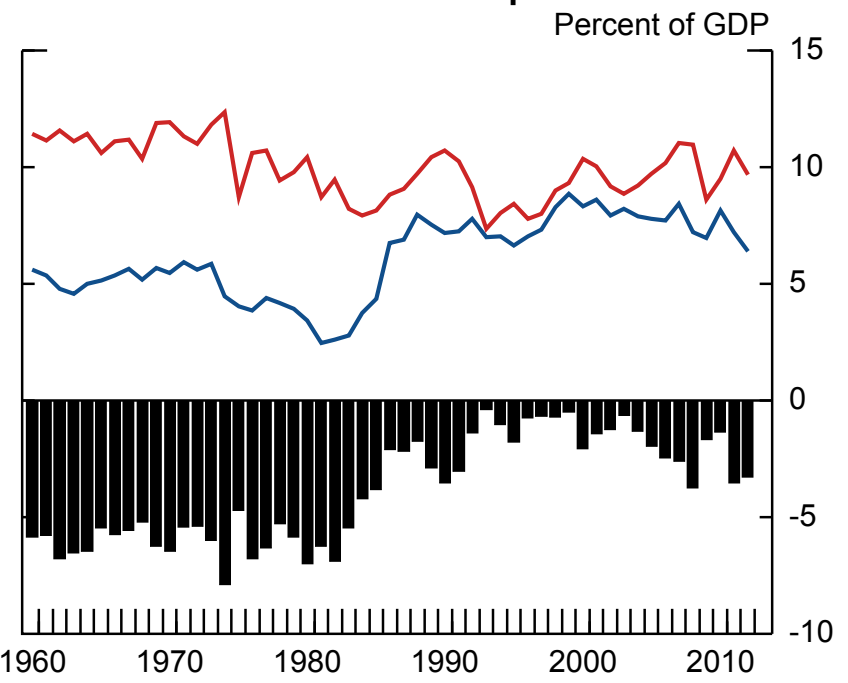

2. Canada - Total Corporations

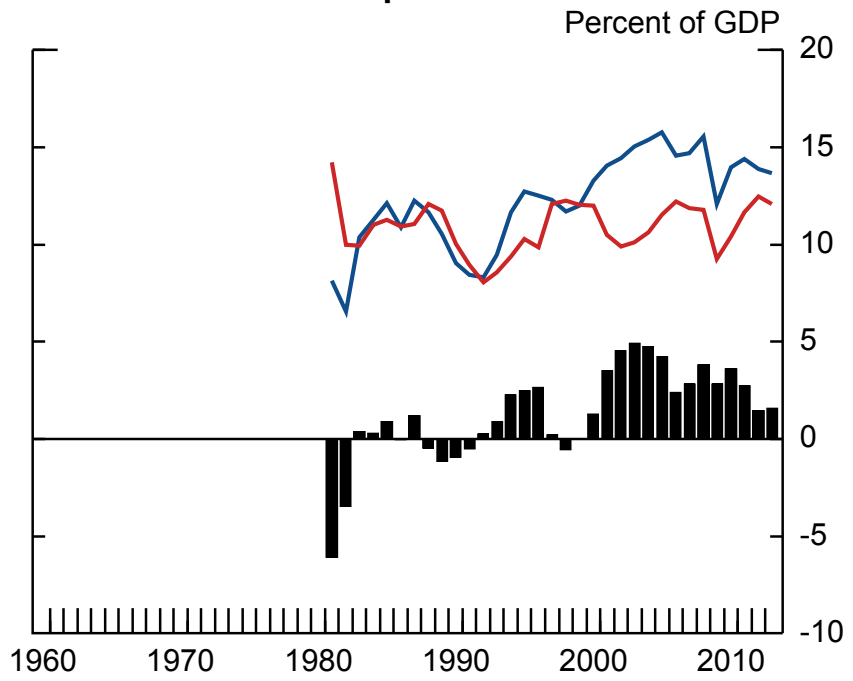

4. Germany - Non-Financial Corporations

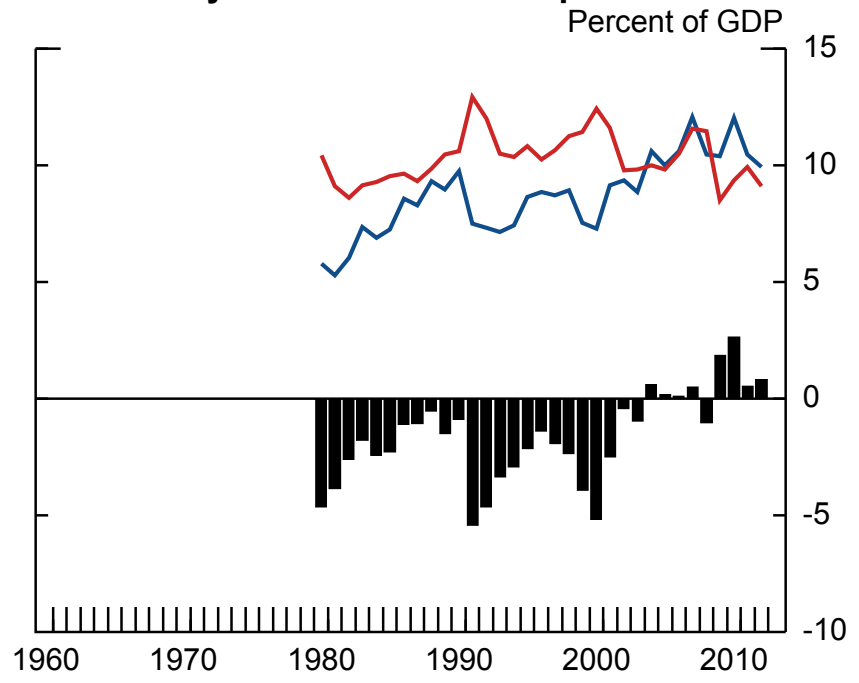

6. Italy - Non-Financial Corporations

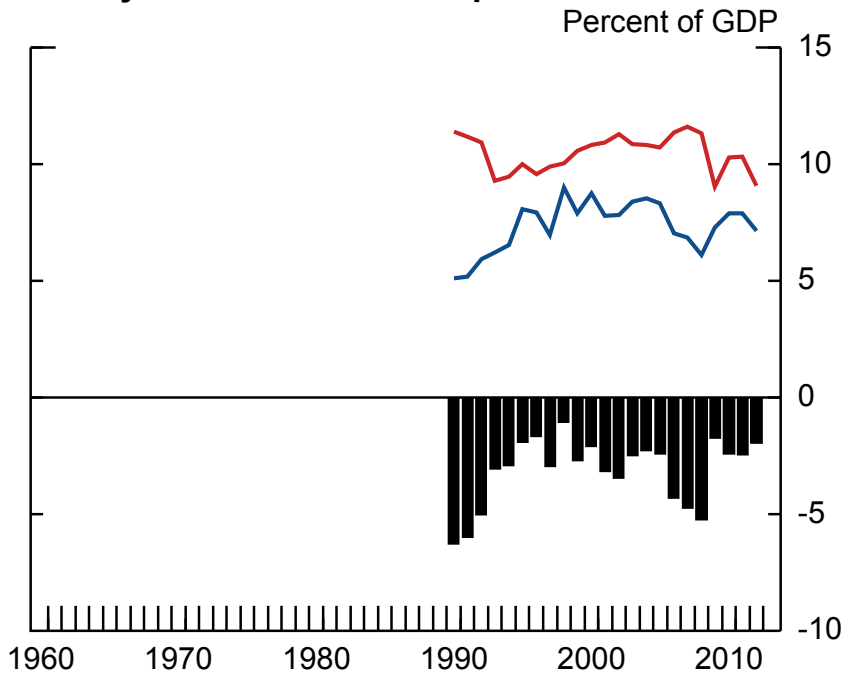


Figure 3

\section{Cash and Short Term Investments}

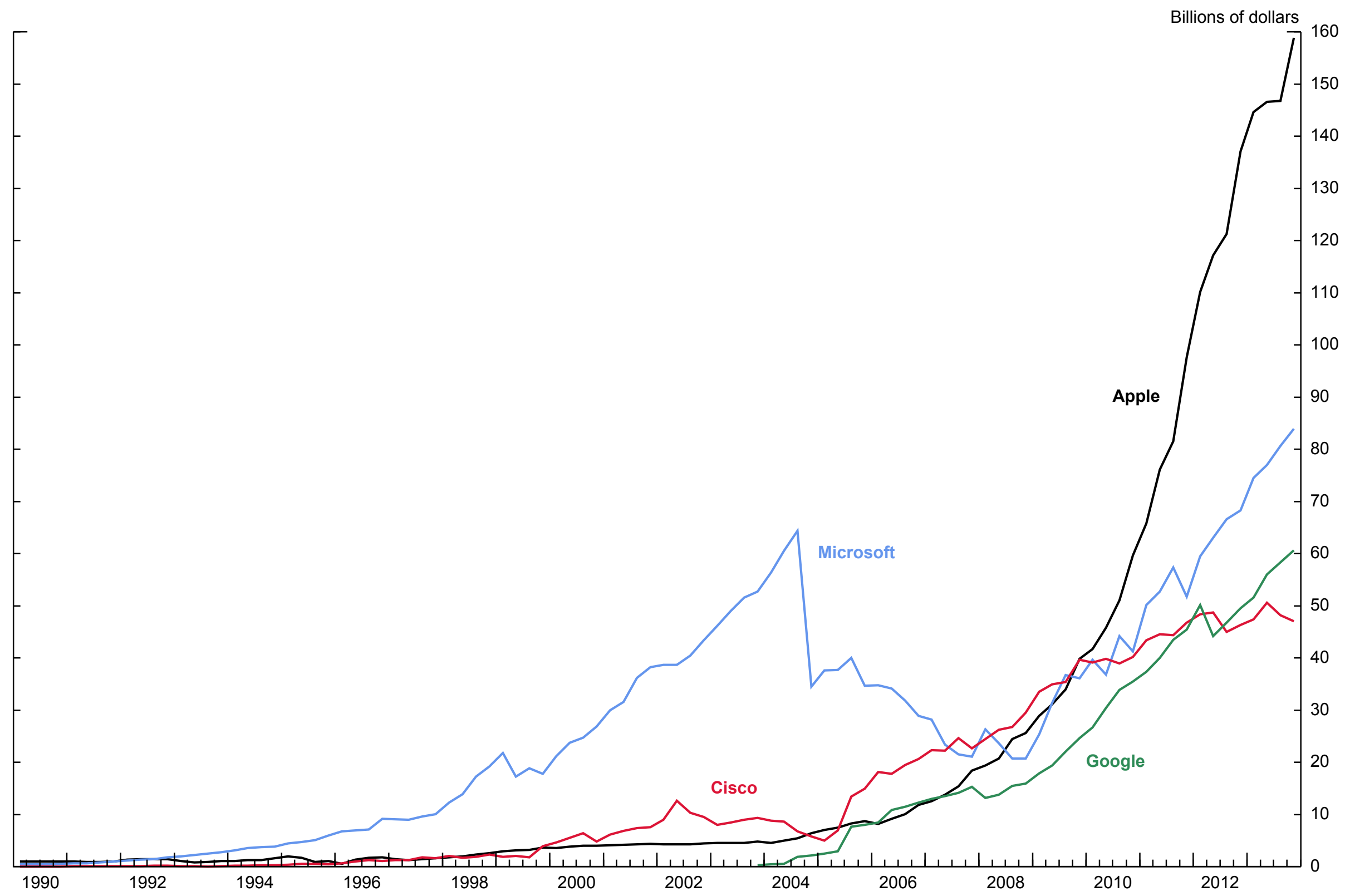


Figure 4

\section{Net Lending and Real GDP Growth, 2009-2012/2013 vs. 2002-2005}

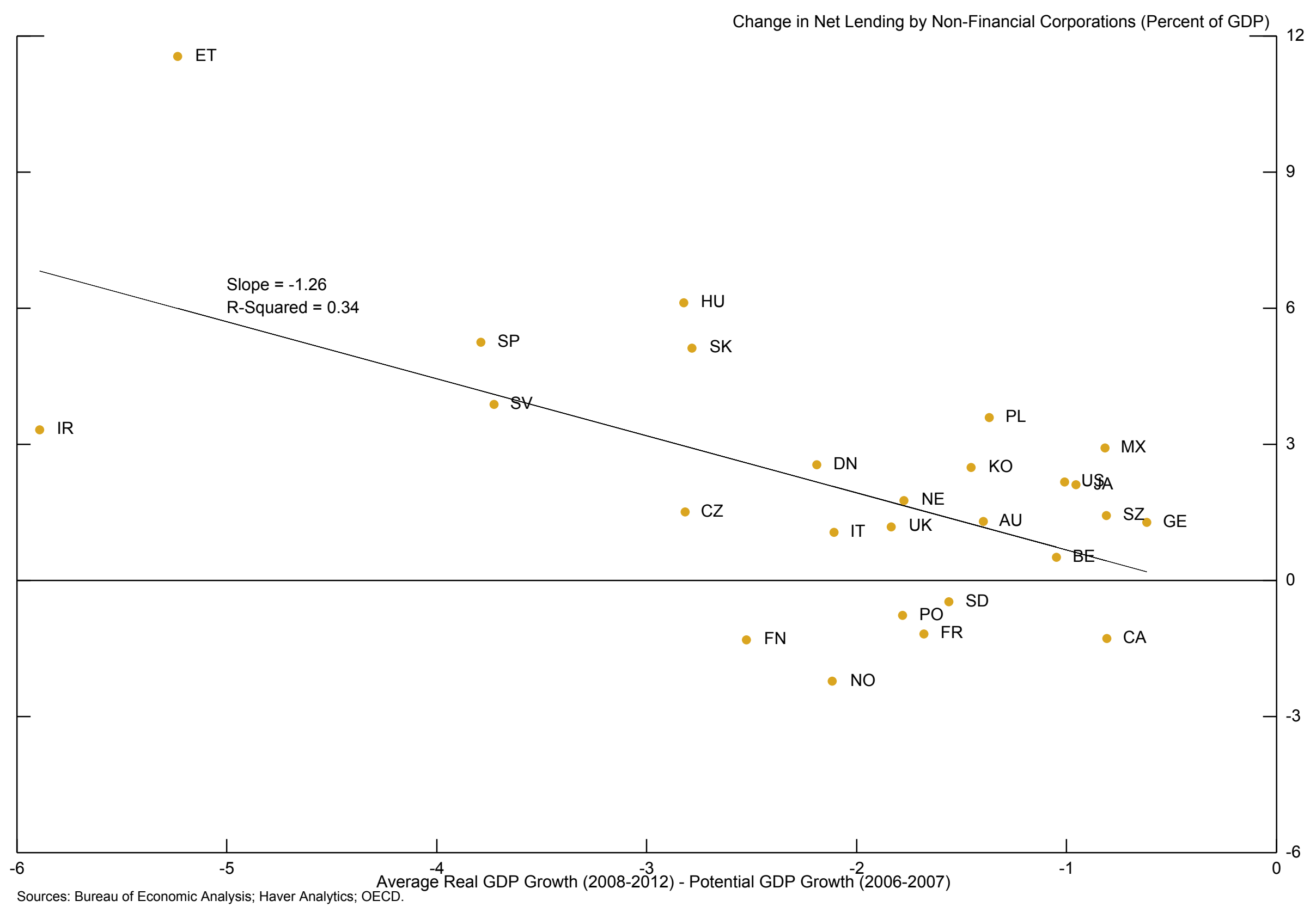




\section{Net Lending and Current Accounts, 2009-2012/2013 vs. 2002-2005}

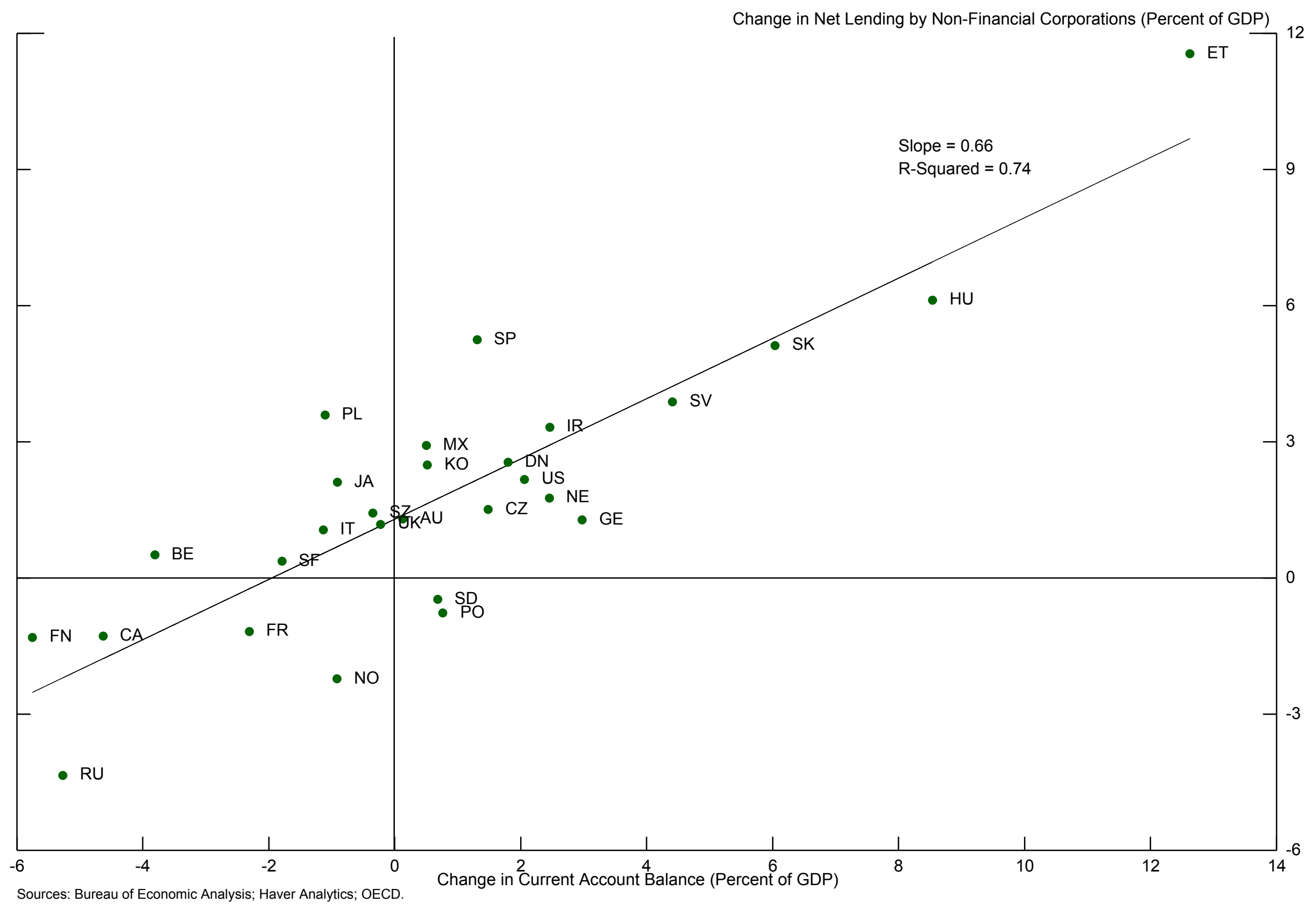


Change in Net Lending by Non-Financial Corporations \& Households, 2009-2012/2013 vs. 2002-2005

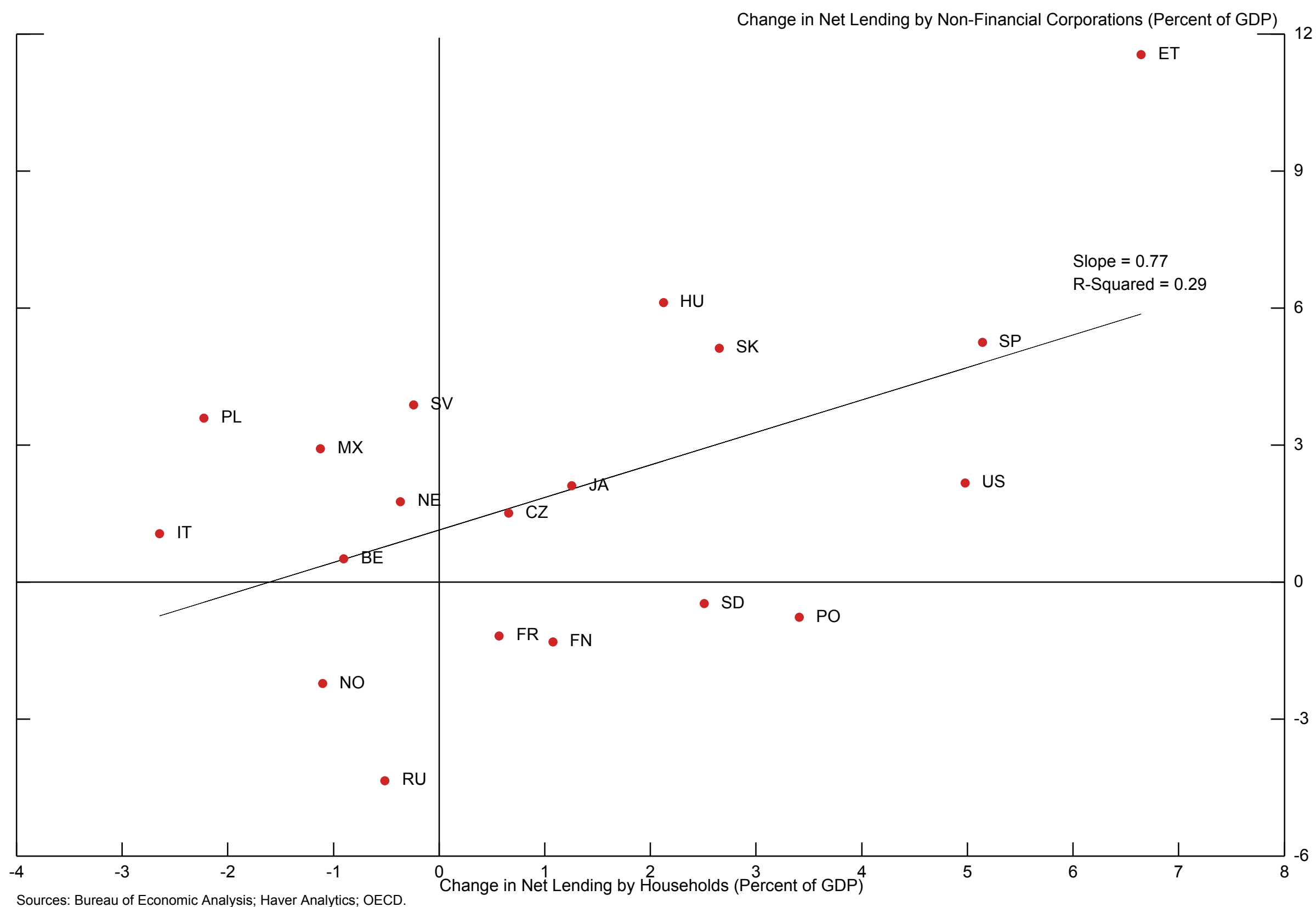




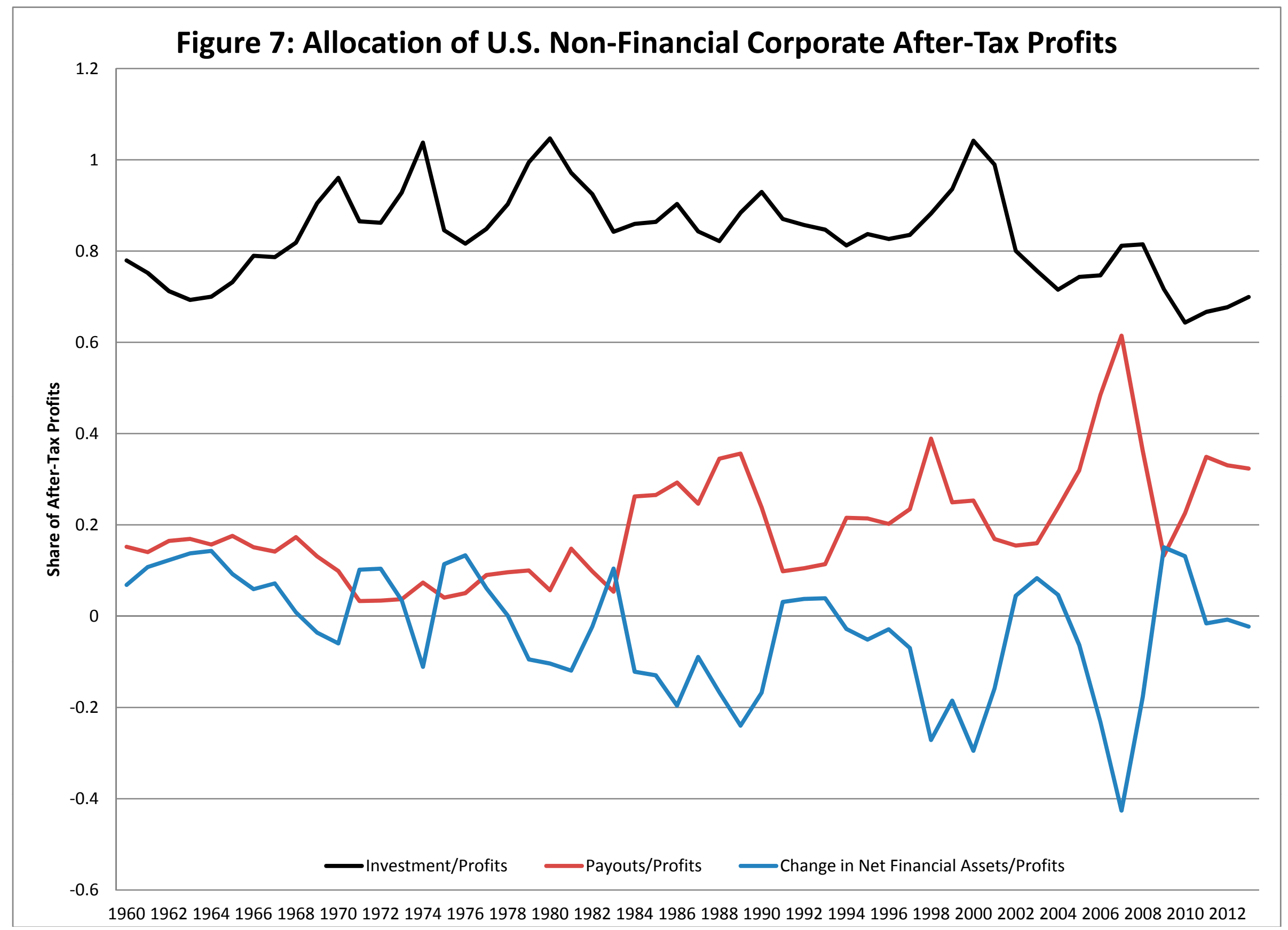


Figure 8: Allocation of Non-Financial Corporate After-Tax Profits

FR

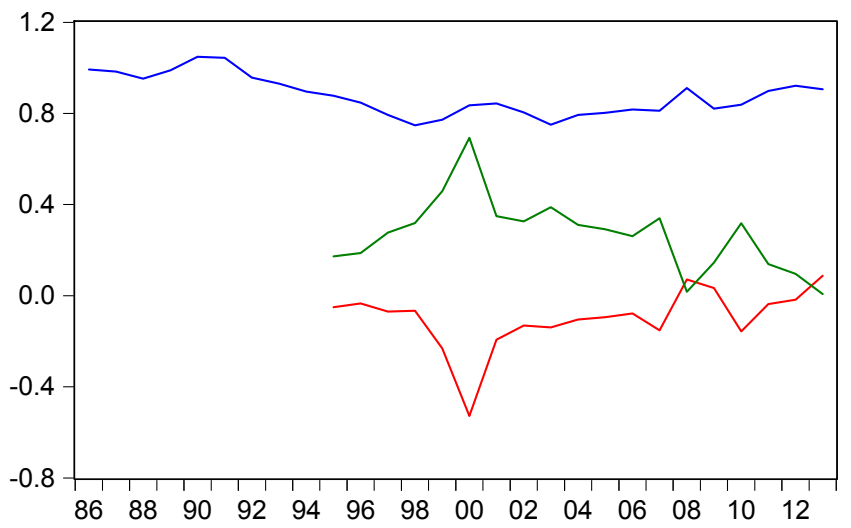

IT

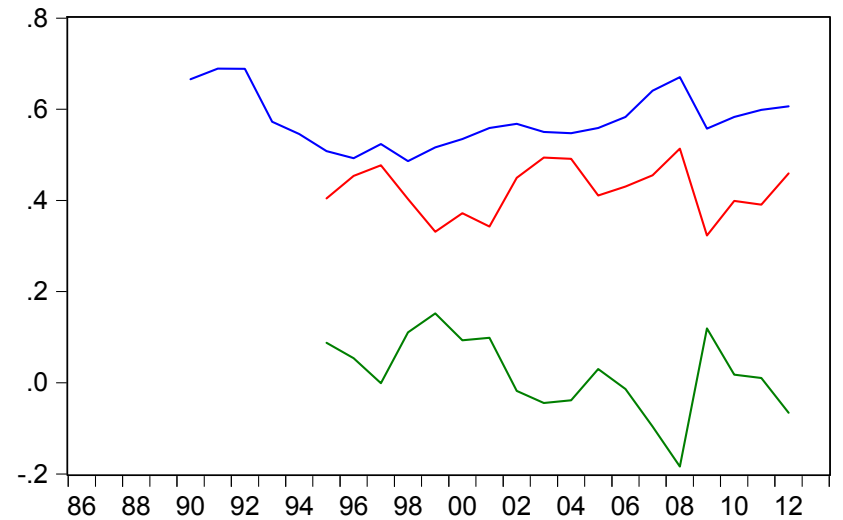

GE

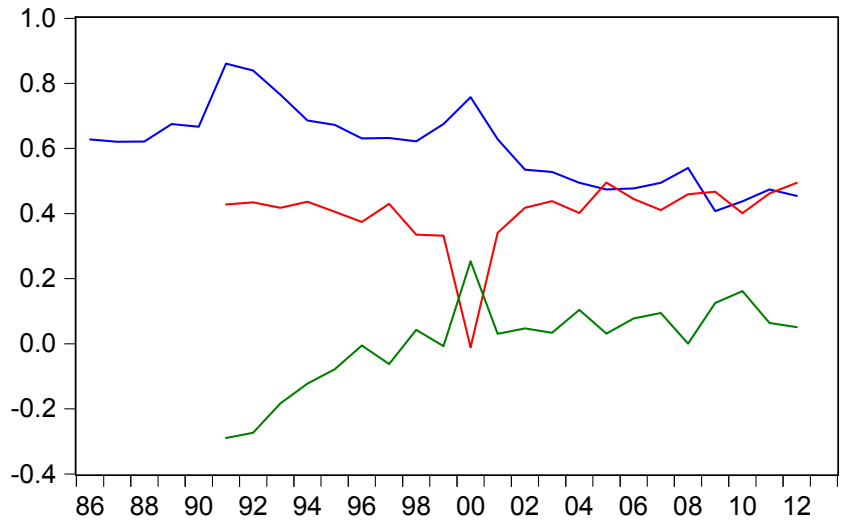

JA

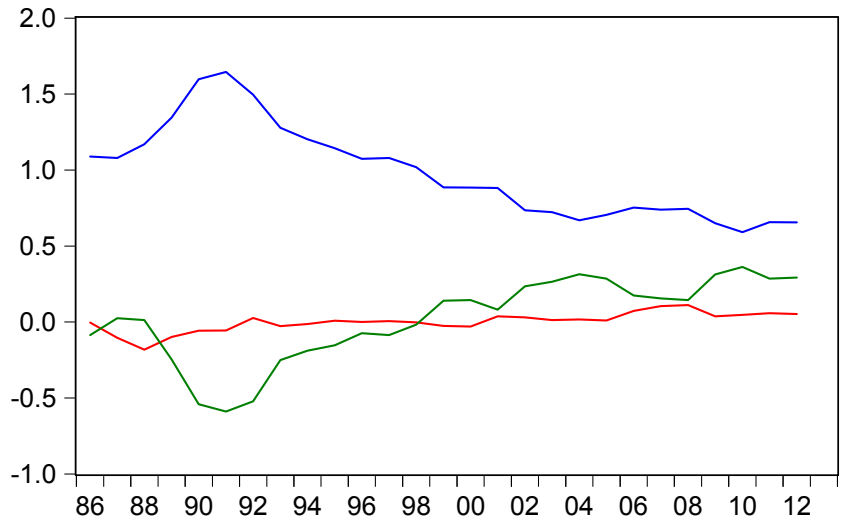

UK

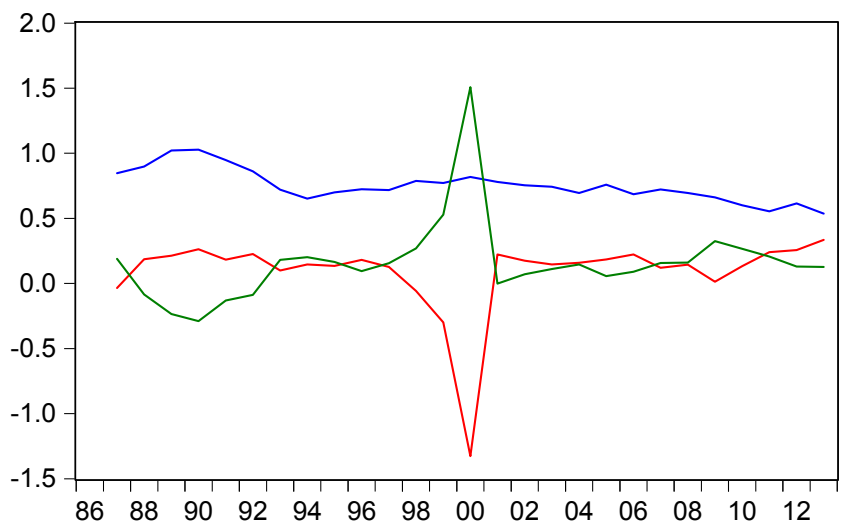




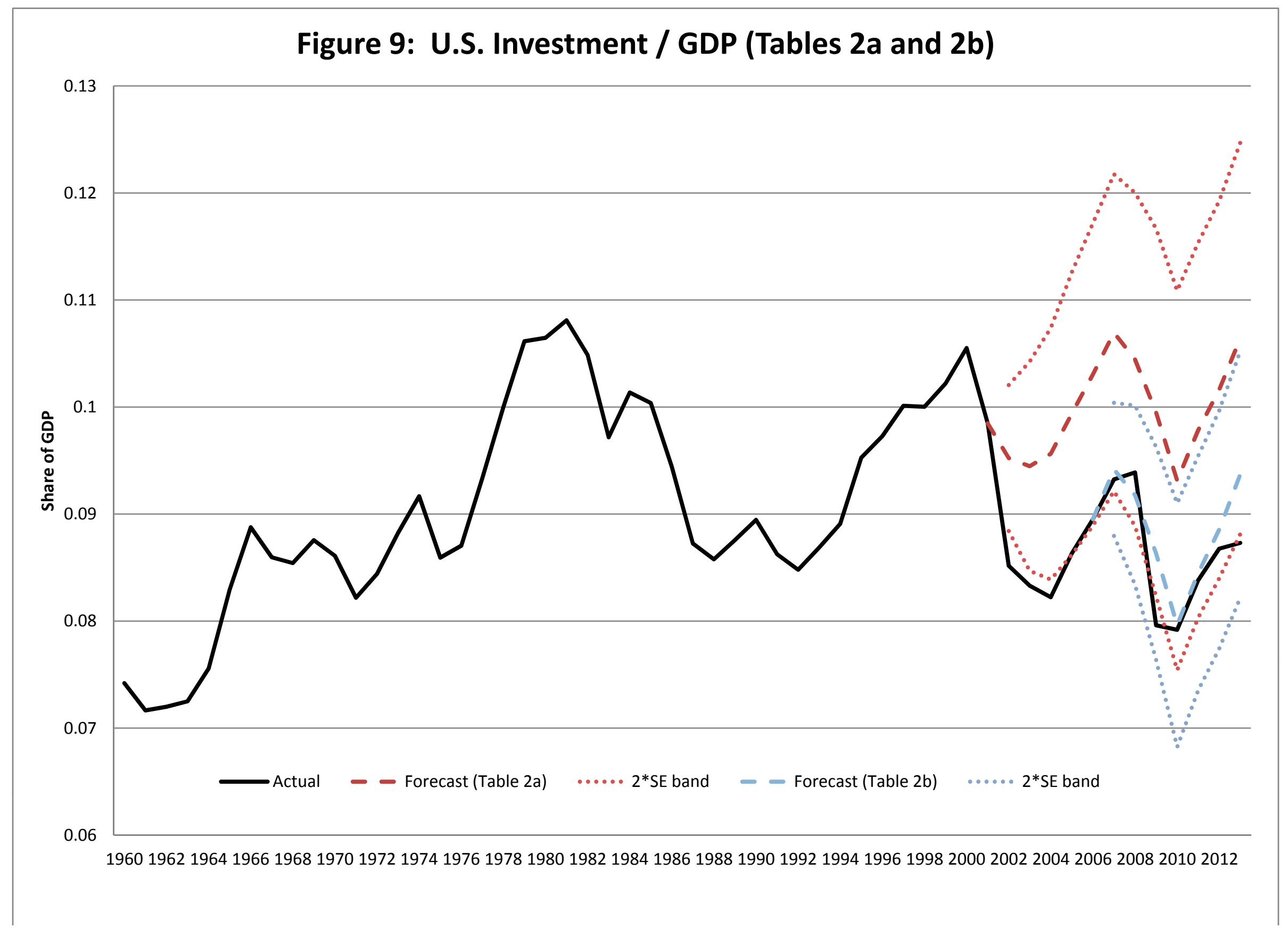




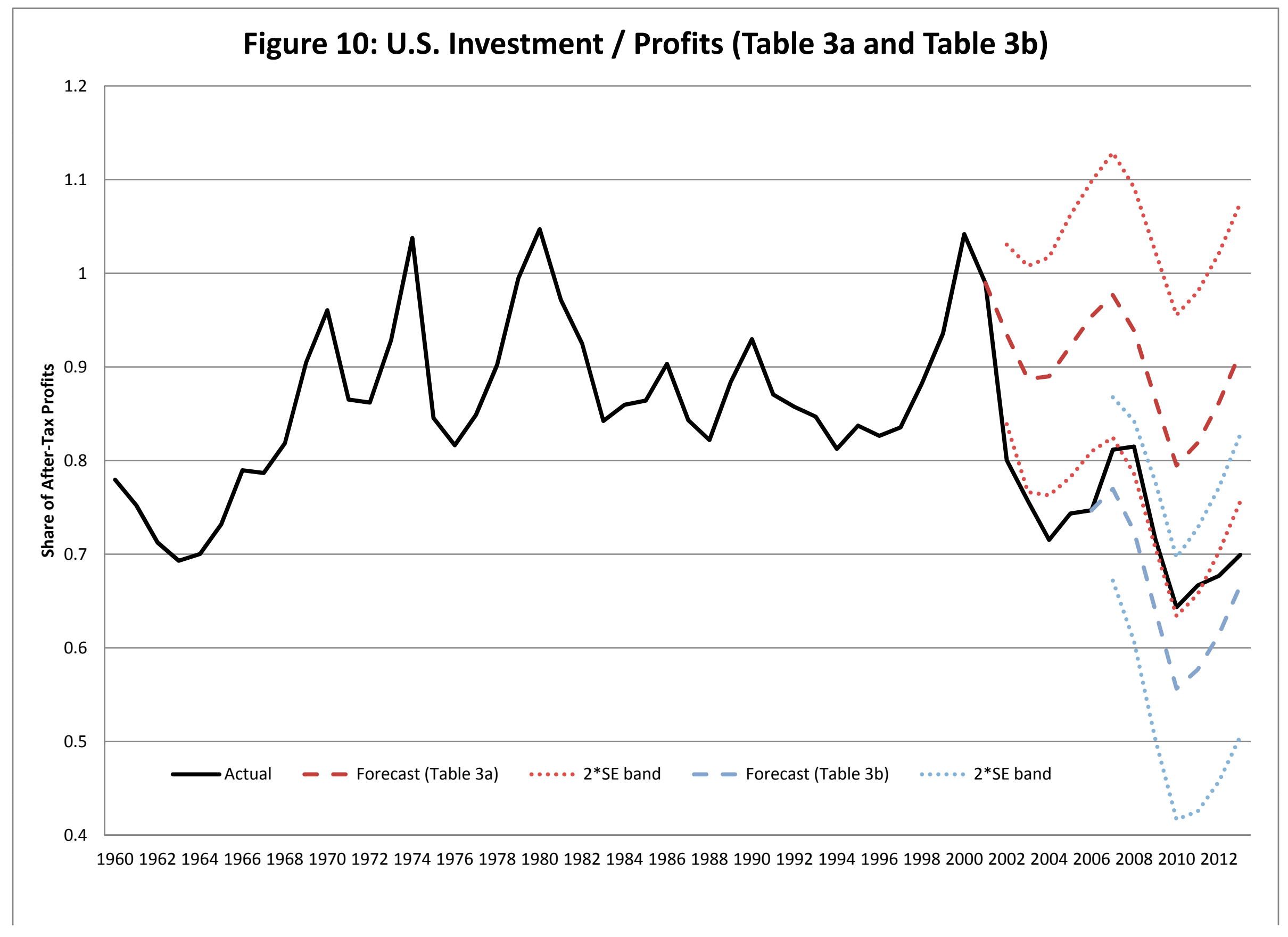


Figure 11: Investment / GDP Panel (Tables 4a and 4b)
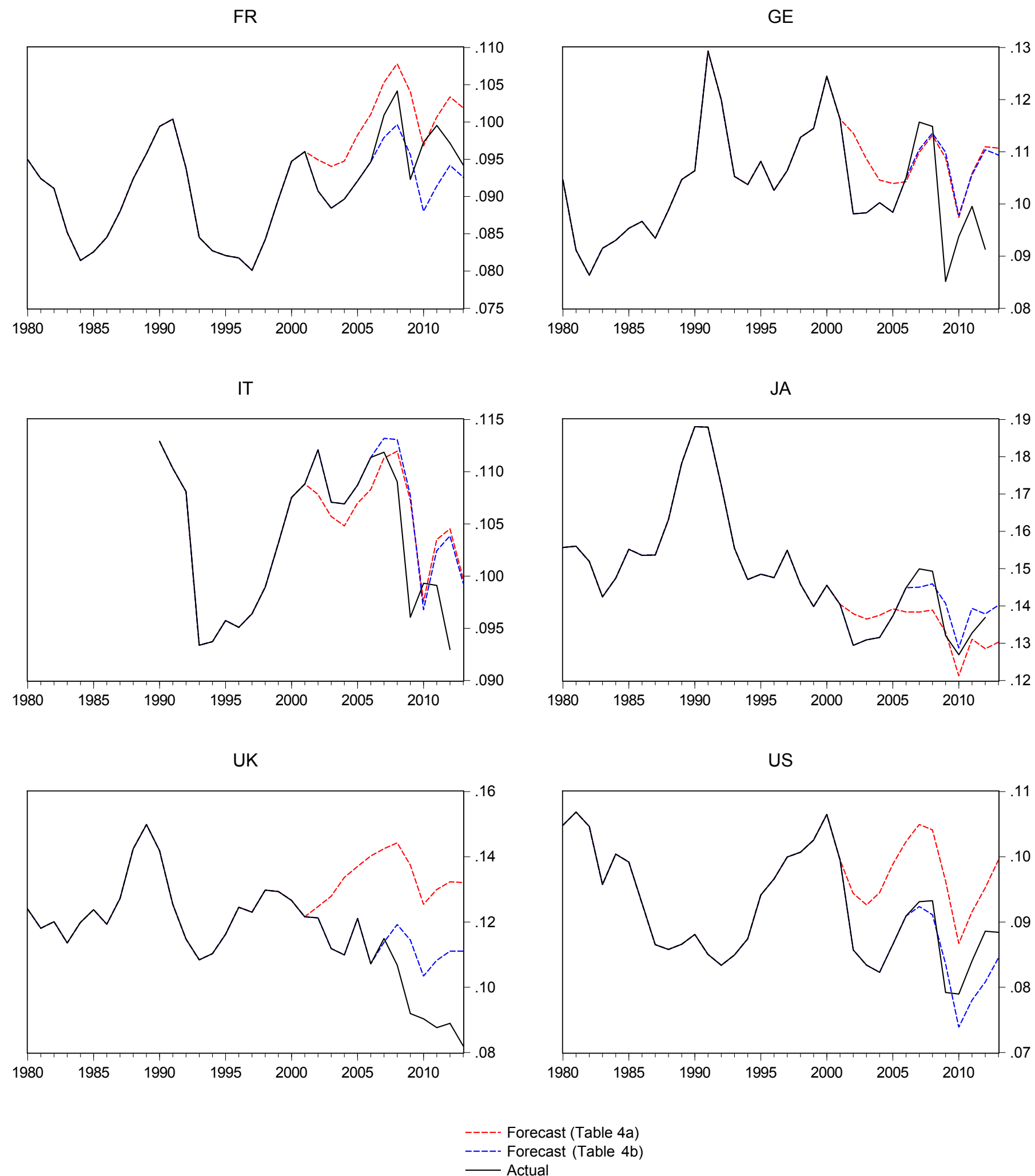
Figure 12: Investment/Profit Panel (Tables 5a and 5b)

FR

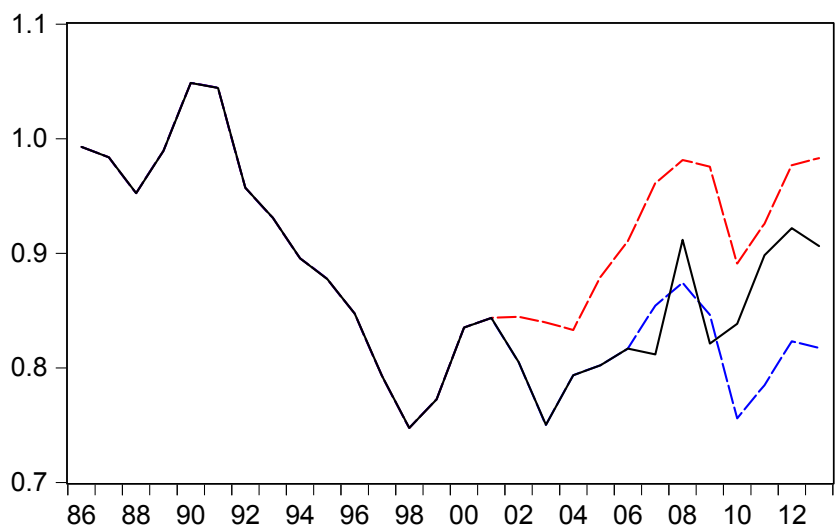

IT

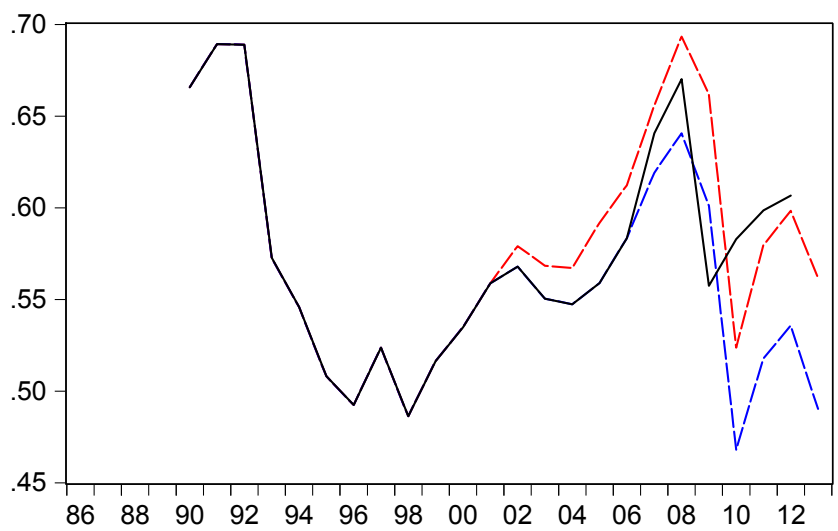

UK

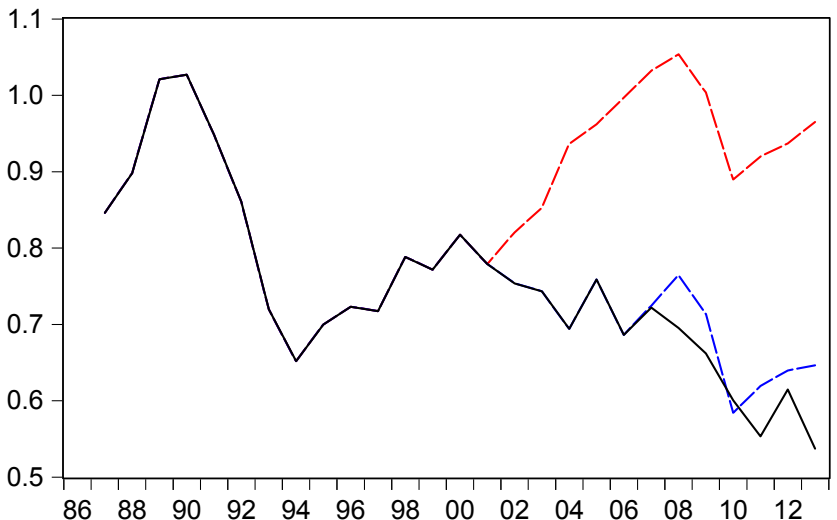

GE

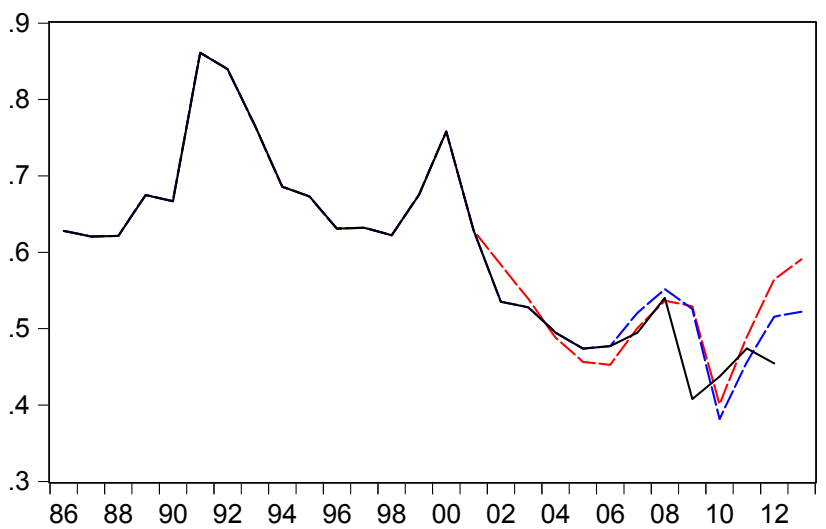

JA

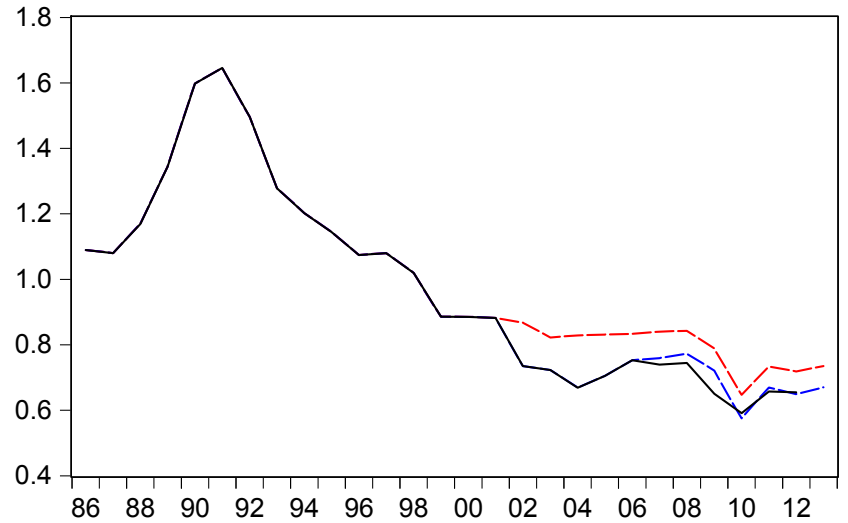

US

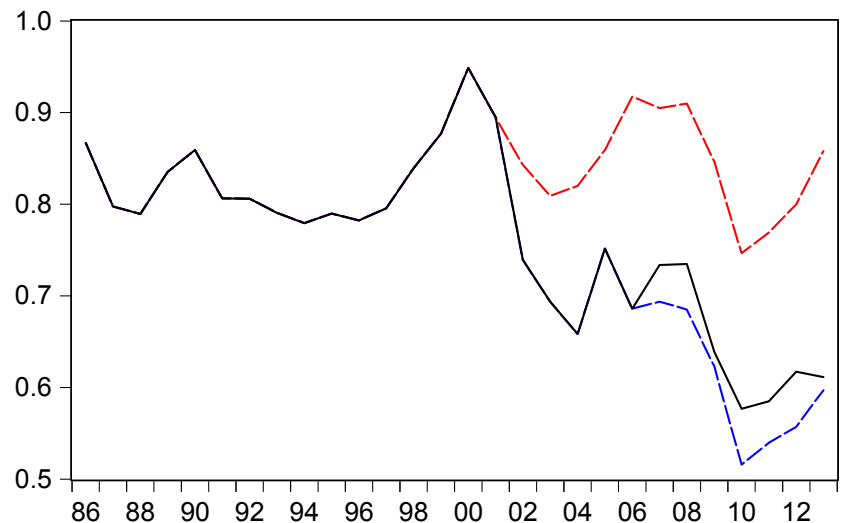




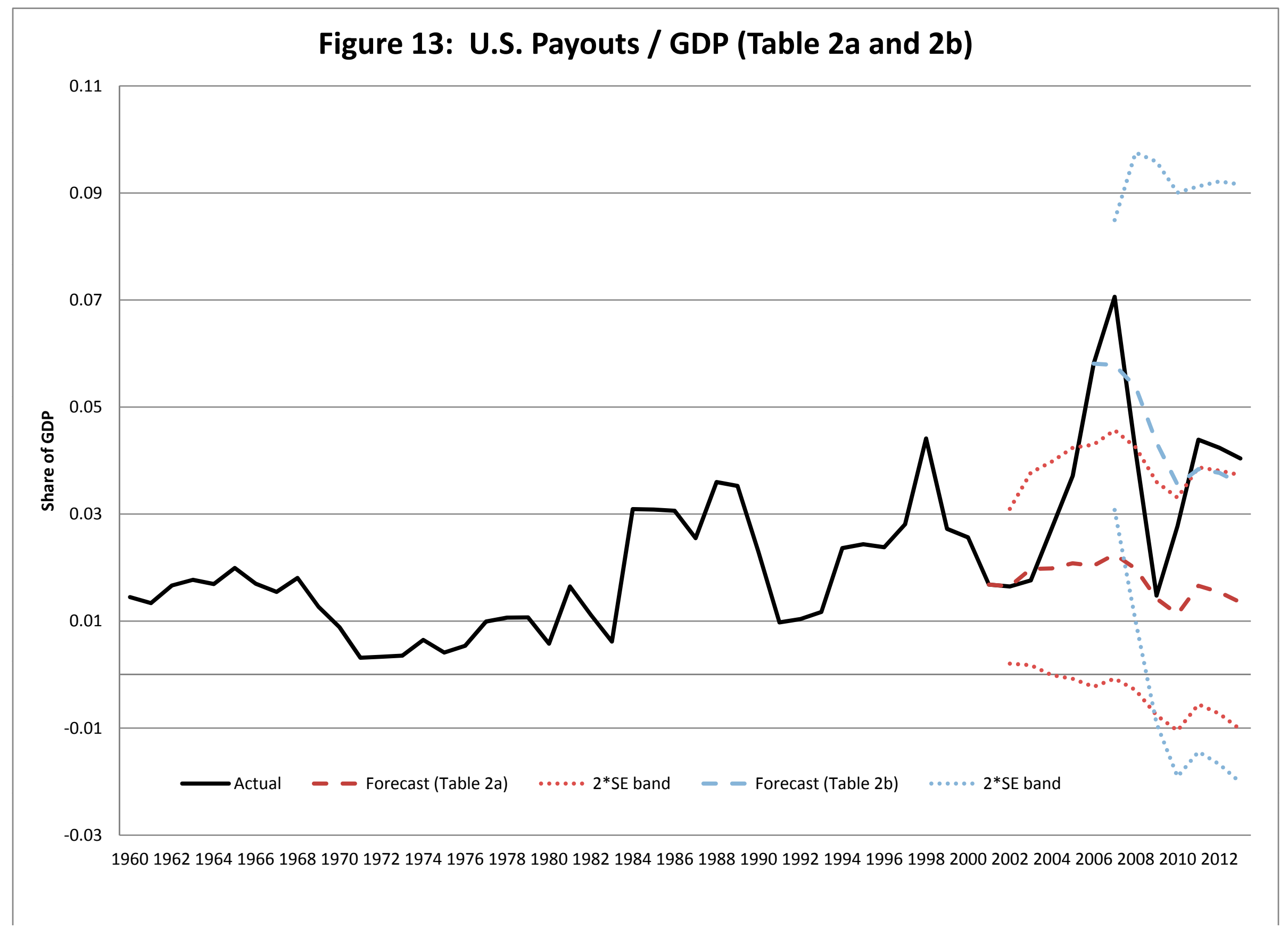




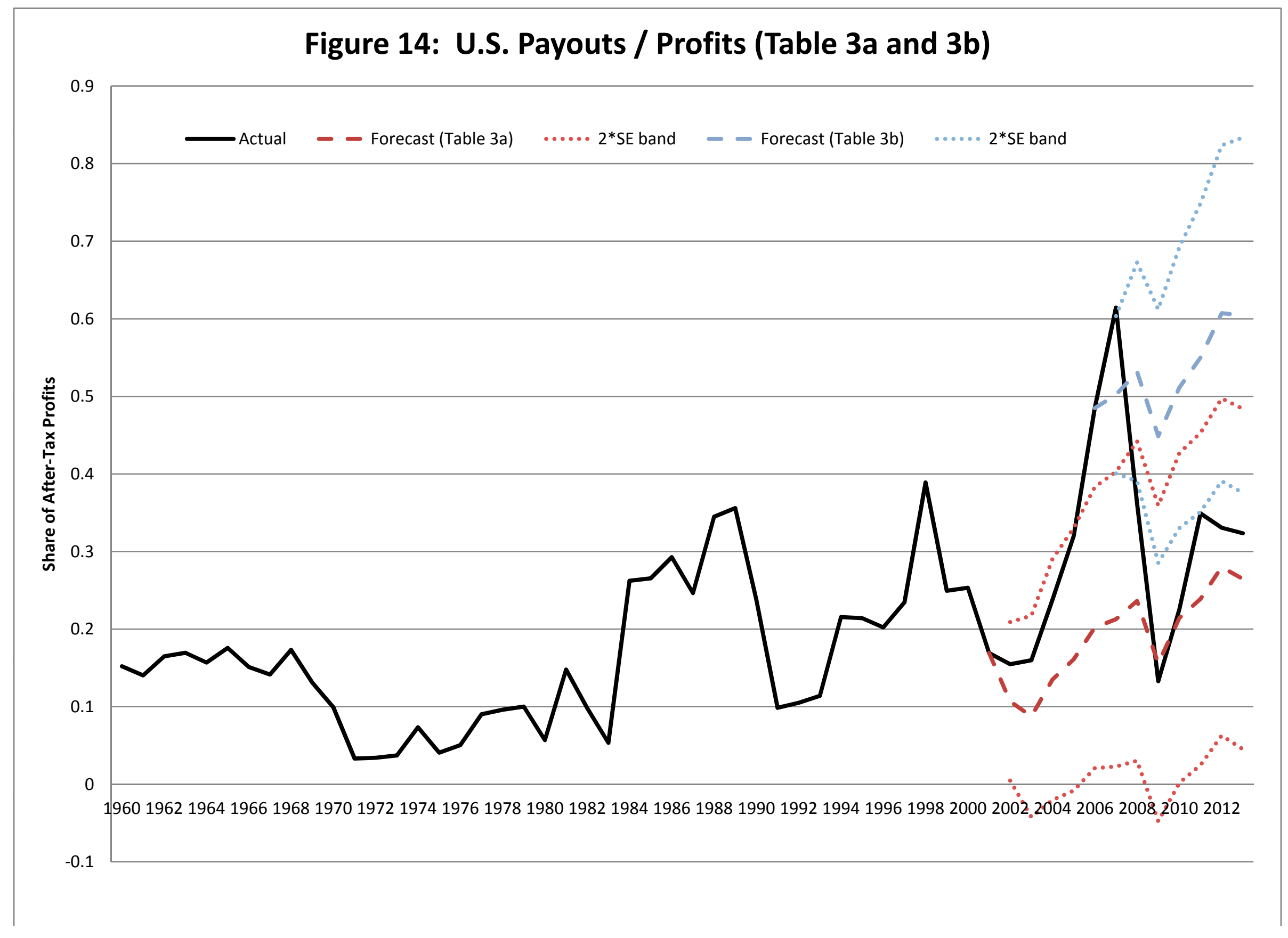


Figure 15: Payouts / GDP Panel (Tables 4a and 4b)
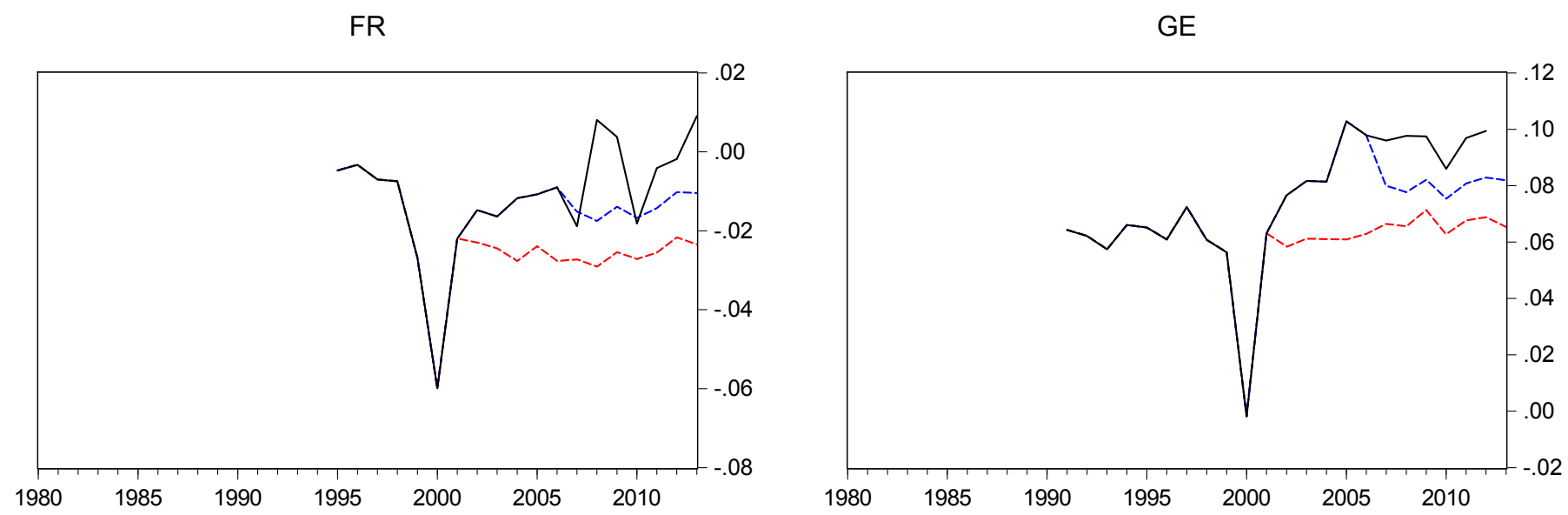

IT

JA
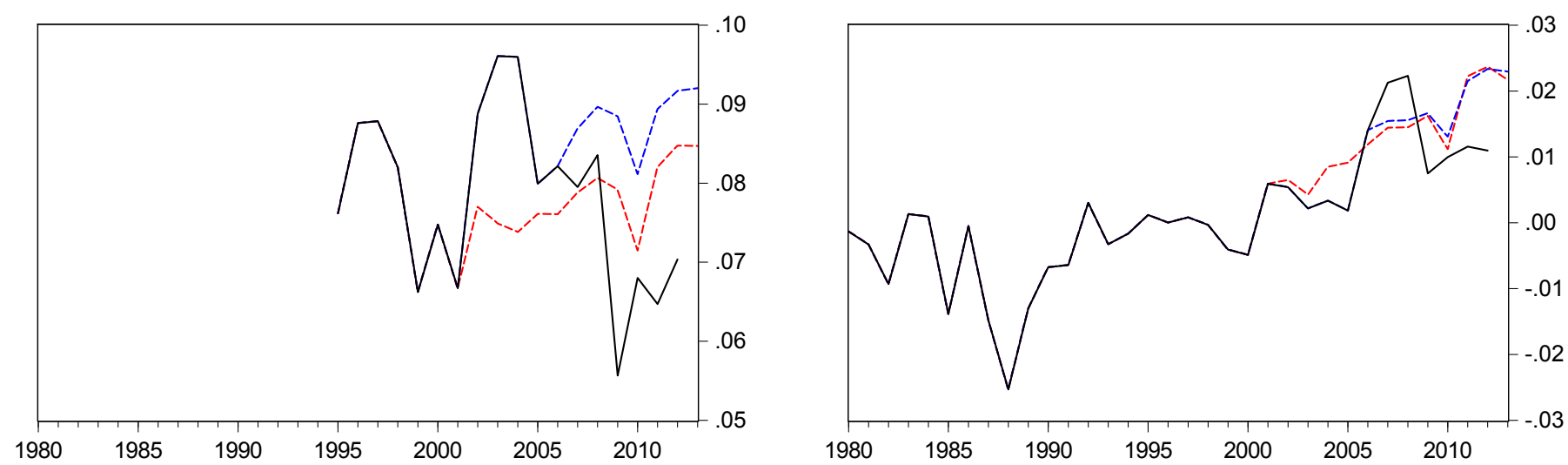

UK

US
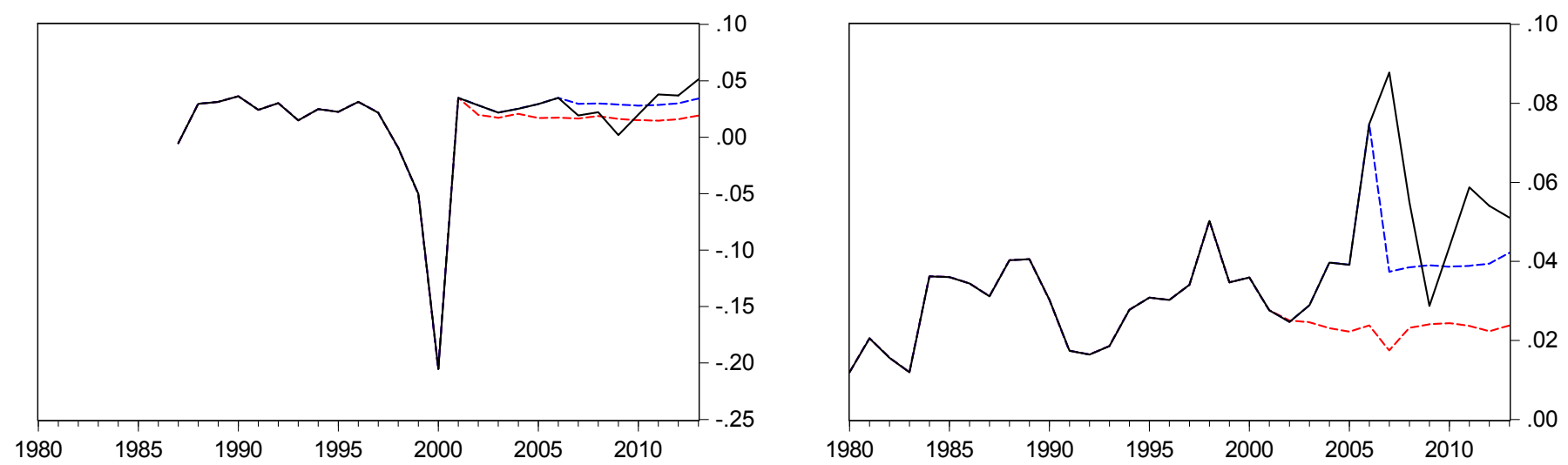

Forecast (Table 4a)

Forecast (Table 4b)

Actual 
Figure 16: Payouts/Profit Panel (Tables 5a and 5b)

FR

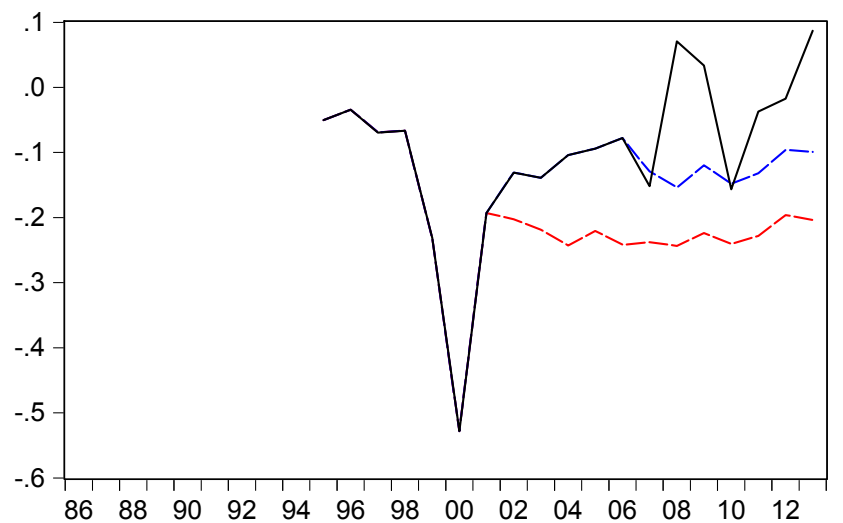

IT

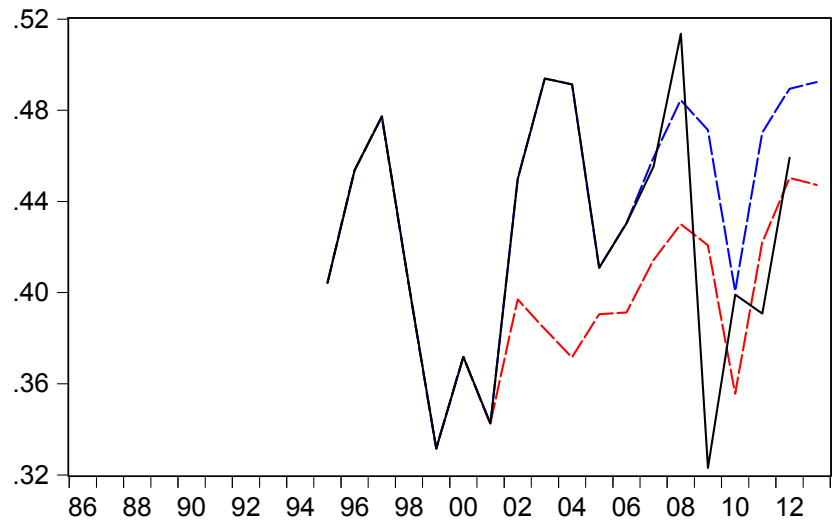

UK

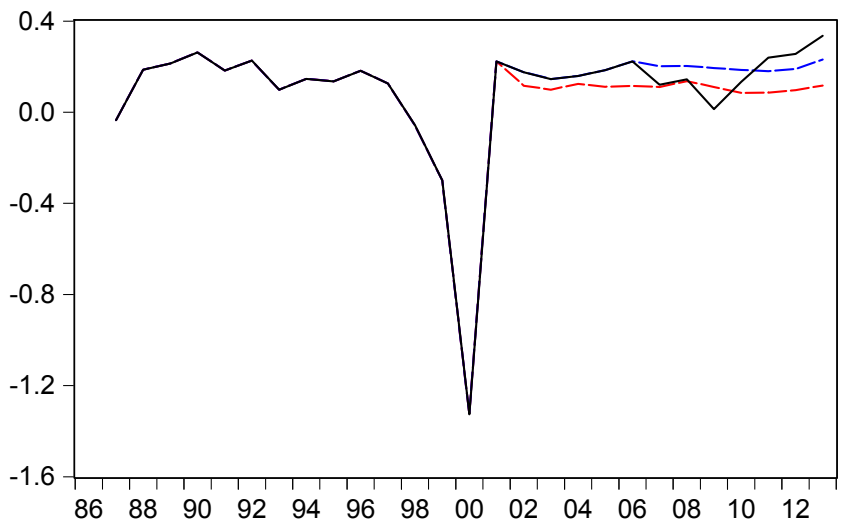

GE

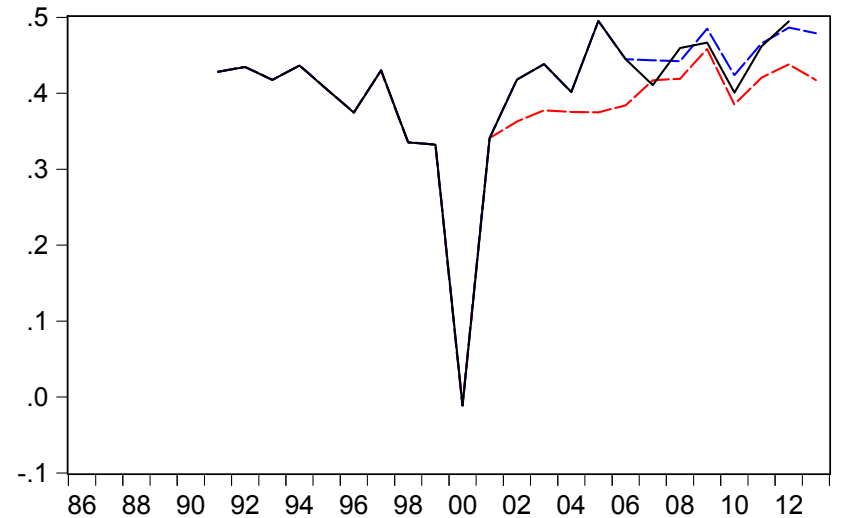

JA

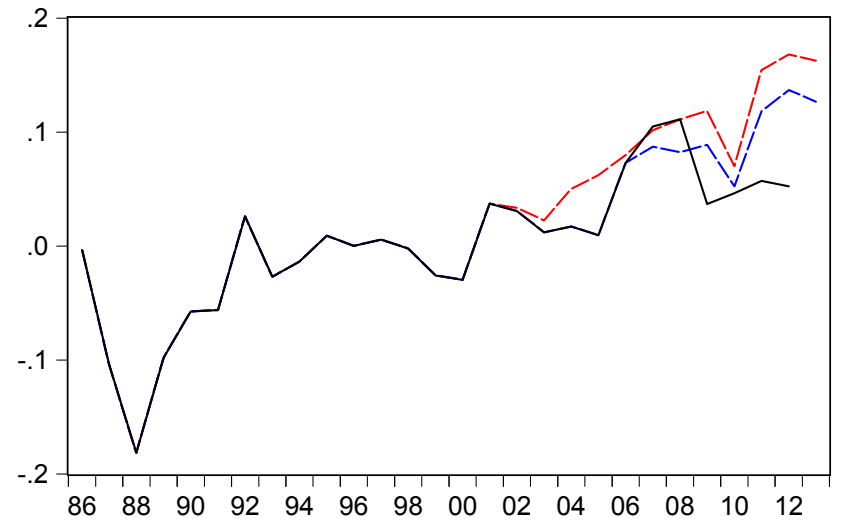

US

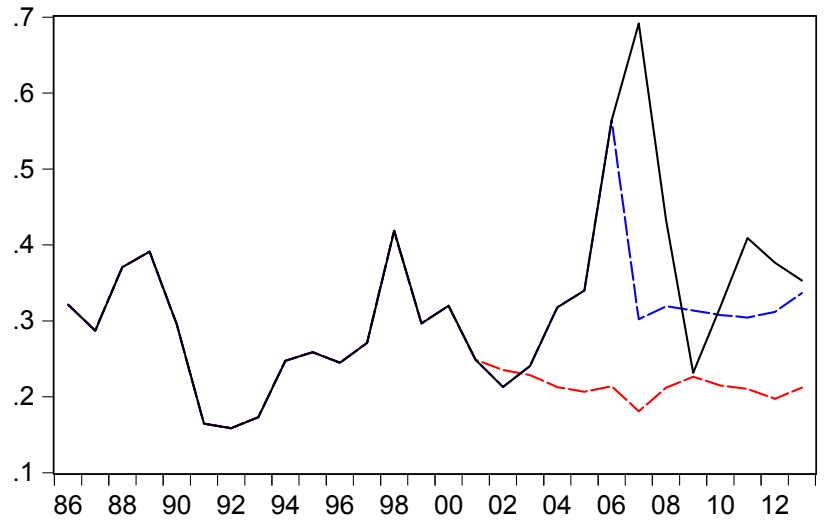




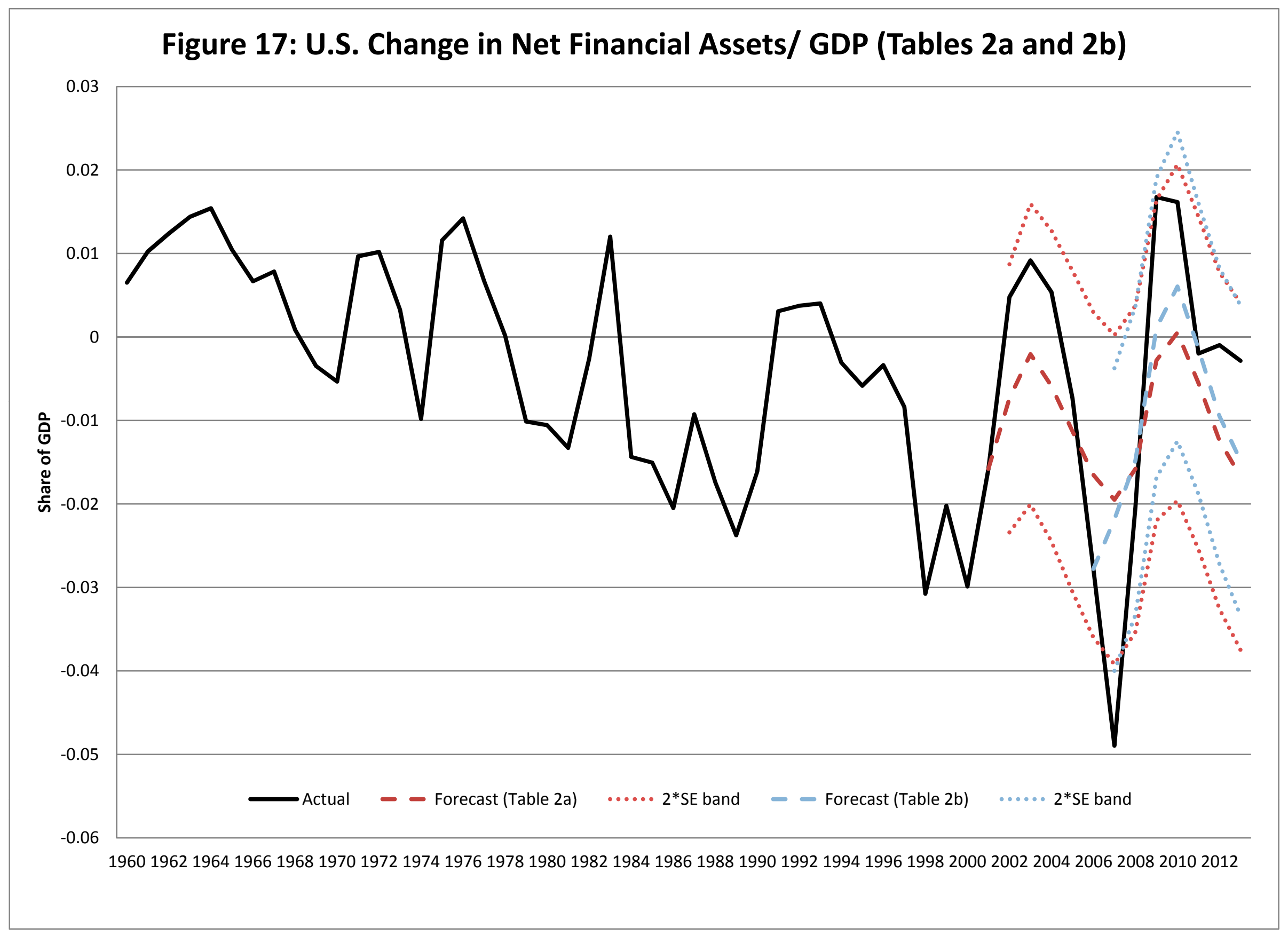




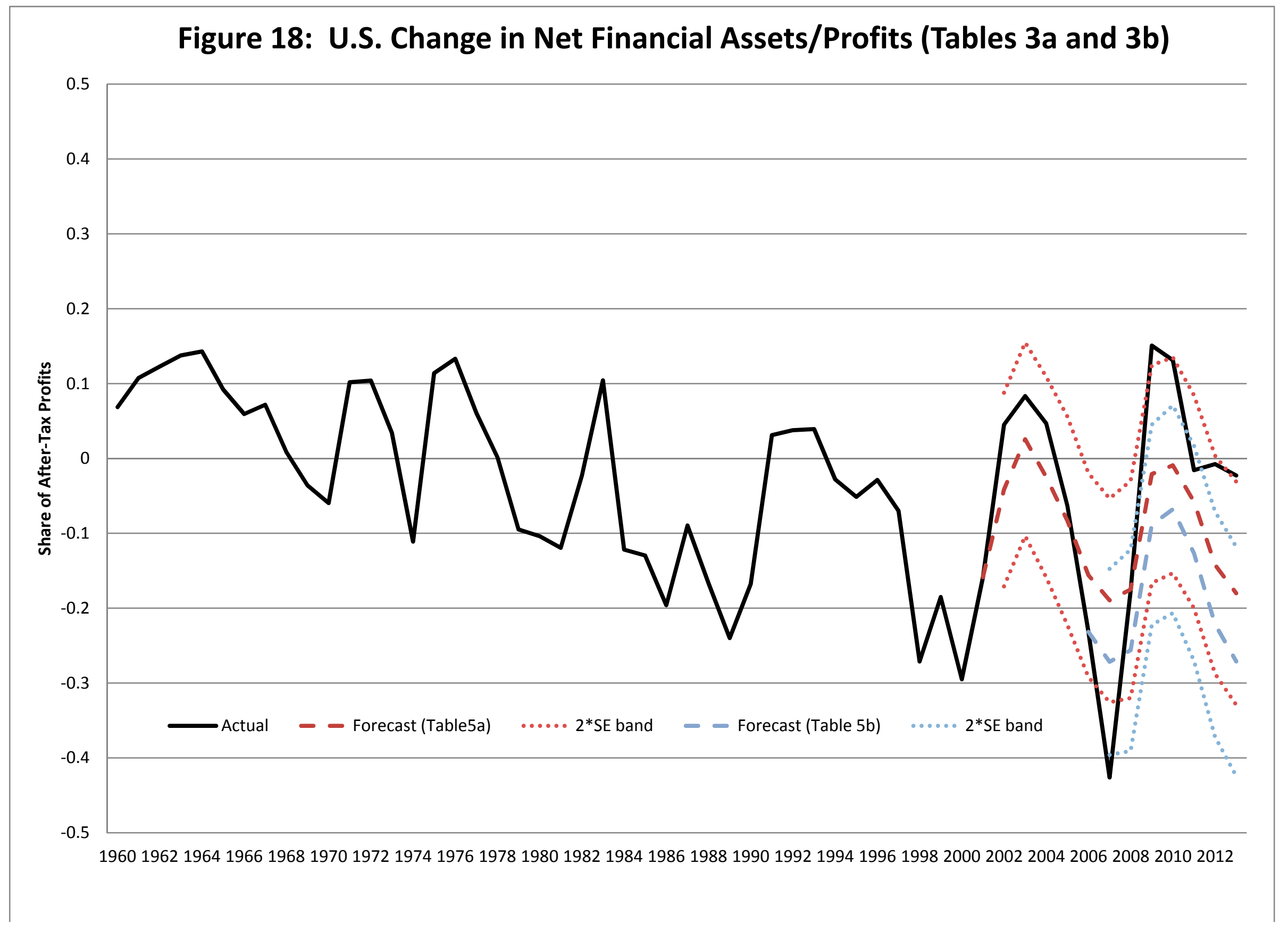


Figure 19: Change in Net Financial Assets / GDP (Tables 4a and 4b)
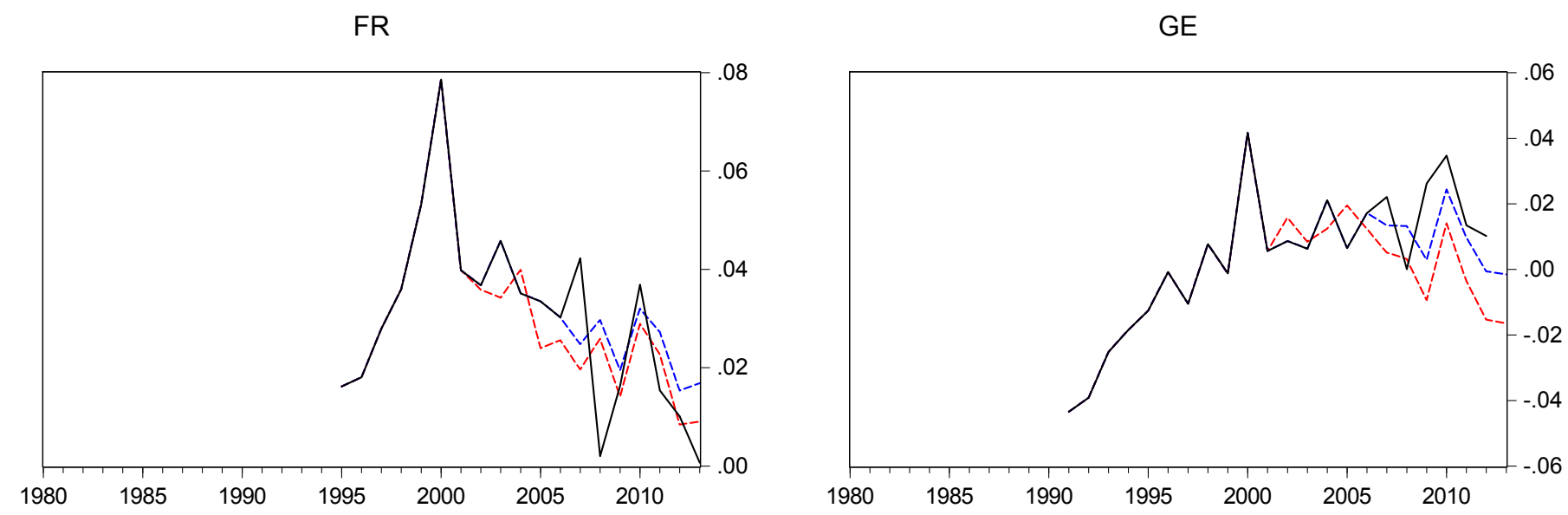

IT

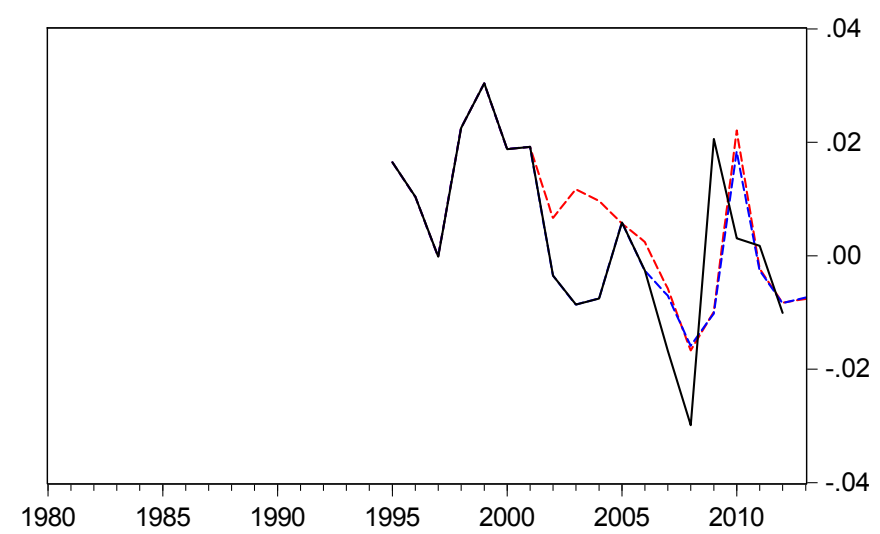

UK

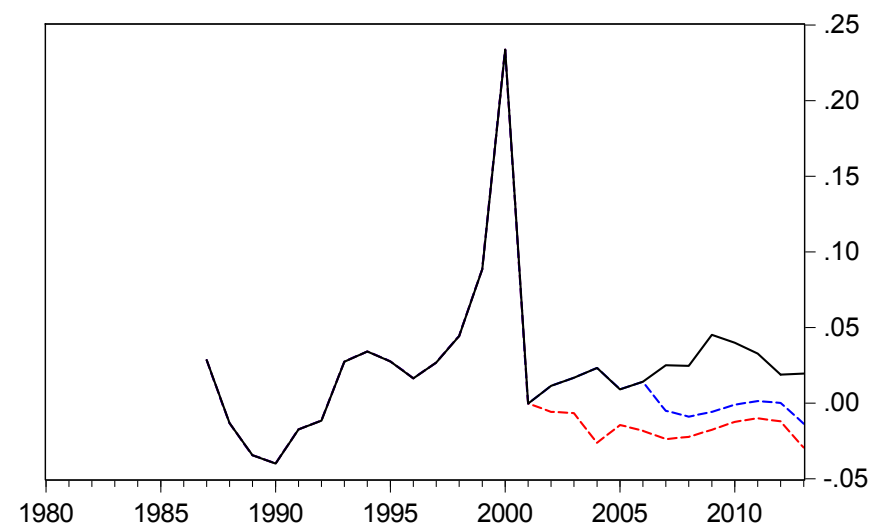

JA

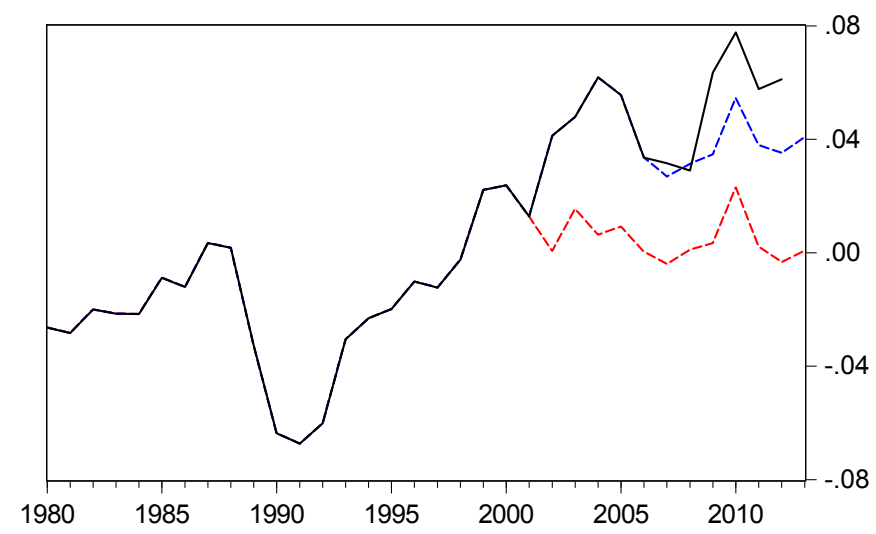

US

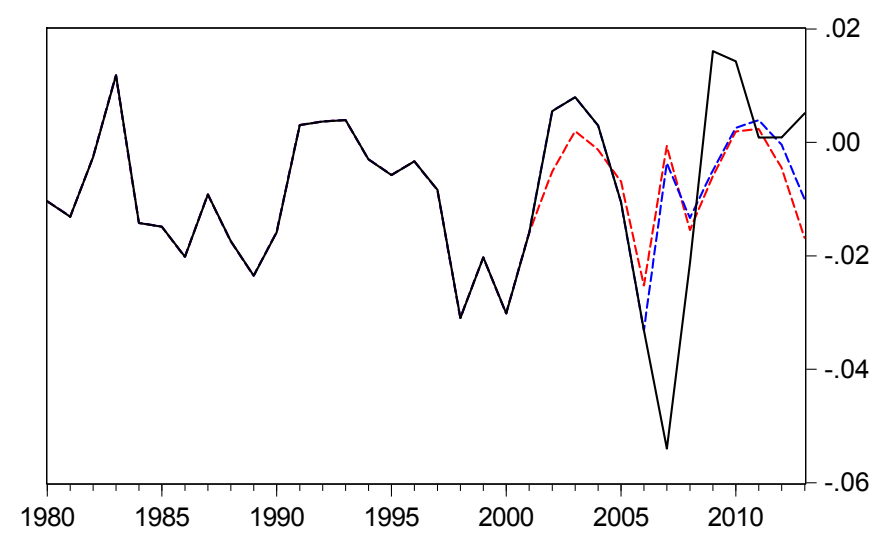



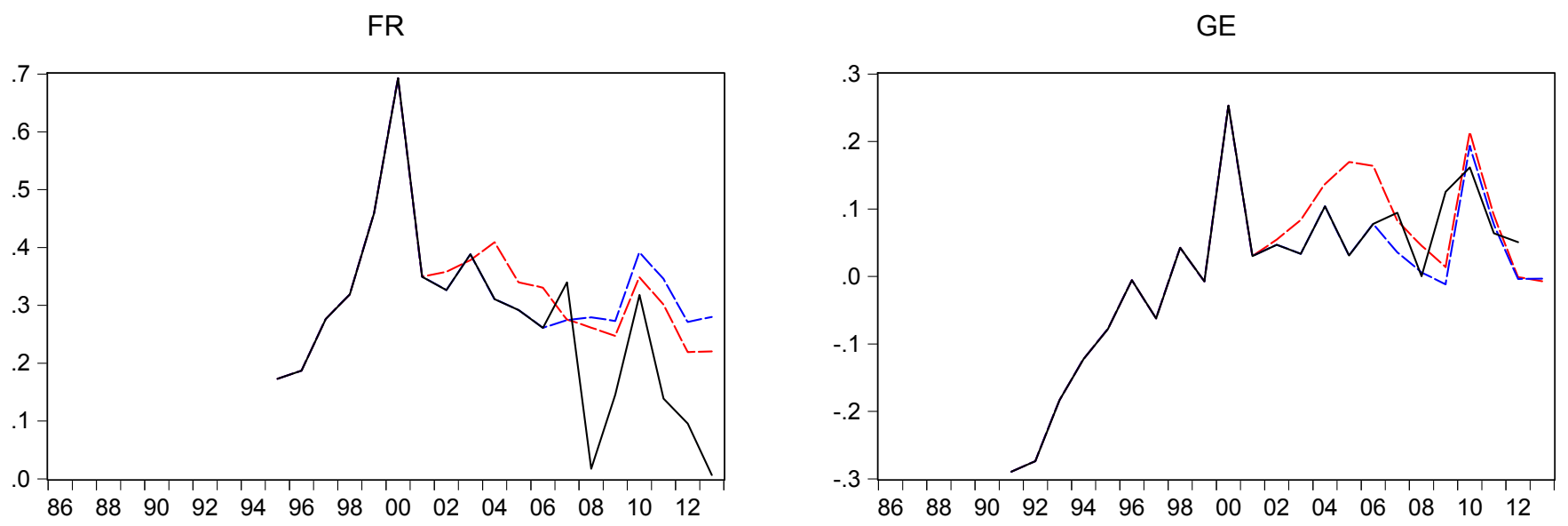

IT
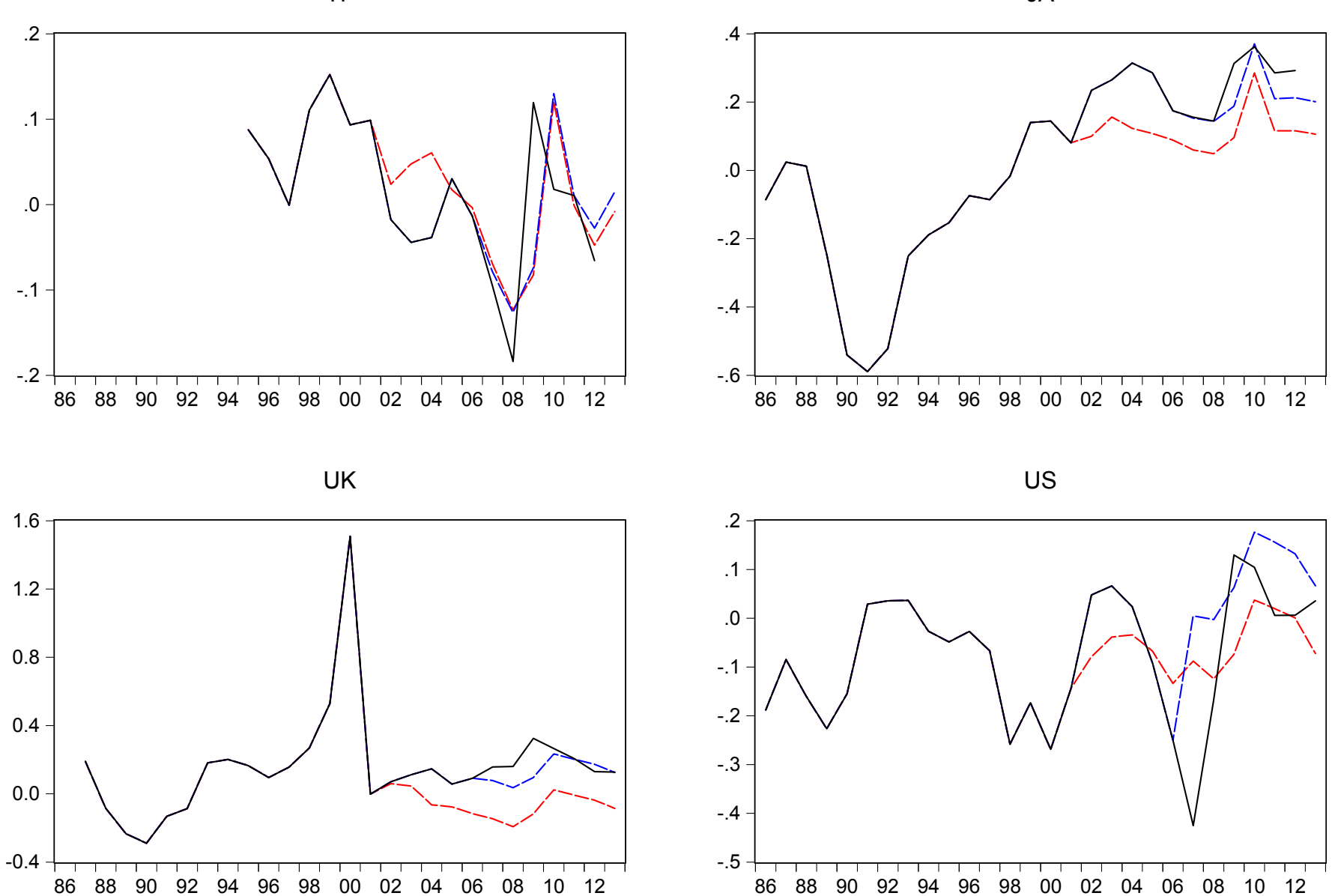
Table 1: U.S. Non-Financial Corporations - Integrated Macroeconomic Accounts

$\frac{\text { As a percent of GDP }}{1960-2007 \quad 2008-2013}$

Non-Financial Account

1

2

3

4

5

6

7

8

9

10

11

12

13

14

15

\begin{abstract}
Gross Value Added
\end{abstract}
Less

Gross Operating Surplus

Less

Profits

Less Net Dividends

Gross Saving

Gross Capital Formation

Net Lending

Financial Account

Net Lending

Acquistion of Financial Assets

Accumulation of Liabilities

of which Equities

\begin{tabular}{rr}
52.3 & 48.9 \\
\hline 32.9 & 28.4 \\
4.5 & 4.2 \\
\hline 14.9 & 16.2 \\
1.7 & 1.8 \\
1.7 & 0.8 \\
\hline 11.6 & 13.7 \\
2.2 & 2.8 \\
\hline 9.3 & 10.9
\end{tabular}

9.2

8.5

0.1

2.4

$\begin{array}{ll}-0.5 & -0.3\end{array}$

$\begin{array}{rr}4.9 & 2.7 \\ 5.4 & 3.0 \\ -1.3 & -2.0\end{array}$


Table 2a: United States 1961 - 2001

(1)

Dependent Variable:

Time Trend

Lagged Dependent

Real Growth (-1)

Real Interest Rate (-1)

Relative Investment Price (-1)

Proportion of Intangibles in Investment

\section{Profit Growth (-1)}

\# Observations

$\mathrm{R}^{\wedge} 2$

SER

DW Stat
(2)

\begin{tabular}{rrr} 
Investment/GDP & Payouts/GDP & $\Delta$ Net Financial Assets/GDP \\
\hline 0.001 & 0.000 & -0.001 \\
3.000 & -0.943 & -2.822 \\
0.741 & 0.491 & 0.221 \\
7.784 & 2.852 & 1.301 \\
0.092 & 0.028 & -0.202 \\
3.492 & 0.461 & -2.825 \\
-0.001 & 0.002 & -0.001 \\
-1.906 & 2.285 & -0.963 \\
0.001 & -0.049 & 0.025 \\
0.109 & -1.455 & 0.659 \\
-0.081 & -0.101 & 0.183 \\
-1.949 & -1.204 & 2.015 \\
0.019 & 0.029 & 0.055 \\
1.729 & 1.600 & 1.889 \\
& & \\
41 & 41 & 41 \\
0.92 & 0.61 & 0.71 \\
0.003 & 0.006 & 0.007 \\
1.73 & 2.10 & 2.55
\end{tabular}

Note: All regressions include an unreported constant. Red bold indicates significance at the 10 percent level.

T-statistics reported under coefficients 
Table 2b: United States 1961 - 2006

Dependent Variable:

(1)

(2)

Time Trend

Lagged Dependent

Investme

Investment

\section{Real Growth (-1)}

Real Interest Rate (-1)

\section{Relative Investment Price (-1)}

Proportion of Intangibles in Investment

\section{Profit Growth (-1)}

\# Observations

$\mathrm{R}^{\wedge} 2$

SER

DW Stat

$\begin{array}{rrr}0.001 & 0.000 & -0.001 \\ 3.273 & -1.121 & -3.148 \\ 0.720 & 0.731 & 0.250 \\ 6.936 & 3.089 & 1.567 \\ 0.111 & -0.029 & -0.232 \\ 4.418 & -0.431 & -3.358 \\ -0.001 & 0.001 & -0.001 \\ -1.620 & 1.386 & -0.873 \\ 0.012 & -0.085 & 0.025 \\ 0.998 & -2.383 & 0.683 \\ -0.086 & -0.200 & 0.219 \\ -2.006 & -1.966 & 2.390 \\ 0.014 & 0.048 & 0.057 \\ 1.308 & 2.347 & 1.933 \\ & & 46 \\ 46 & 46 & 0.69 \\ 0.90 & 0.63 & 0.007 \\ 0.003 & 0.007 & 2.28 \\ 1.50 & 1.78 & \end{array}$

Note: All regressions include an unreported constant. Red bold indicates significance at the 10 percent level.

T-statistics reported under coefficients 
Table 2c: United States 1961 - 2013

Dependent Variable:

(1)

(2)

Time Trend

Lagged Dependent

\begin{tabular}{rrr} 
Investment/GDP & Payouts/GDP & $\Delta$ Net Financial Assets/GDP \\
\hline 0.001 & 0.000 & -0.001 \\
3.153 & -0.717 & -2.363 \\
0.666 & 0.546 & 0.346 \\
6.581 & 3.472 & 2.648 \\
0.086 & 0.035 & -0.214 \\
3.383 & 0.476 & -3.570 \\
0.000 & 0.001 & -0.001 \\
-0.359 & 1.877 & -1.730 \\
-0.003 & -0.085 & 0.075 \\
-0.204 & -2.074 & 1.840 \\
-0.133 & -0.186 & 0.339 \\
-2.970 & -1.591 & 3.126 \\
0.011 & 0.051 & 0.028 \\
1.093 & 2.269 & 0.943 \\
& & \\
53 & 53 & 53 \\
0.88 & 0.67 & 0.68 \\
0.003 & 0.008 & 1.94 \\
1.54 & 1.64 &
\end{tabular}

Note: All regressions include an unreported constant. Red bold indicates significance at the 10 percent level.

T-statistics reported under coefficients 
Table 3a: Share of Profits- United States 1961 - 2001

(1)

(2)

Dependent Variable:

Investment

Time Trend

Lagged Investment/Profits

$\begin{array}{rrr}0.004 & 0.006 & -0.010 \\ 1.637 & 2.840 & -3.229 \\ 0.740 & -0.806 & 0.066 \\ 4.439 & -4.909 & 0.308 \\ -0.067 & 0.339 & -0.273 \\ -0.484 & 1.997 & -1.271 \\ 1.817 & -0.479 & -1.338 \\ 2.880 & -0.795 & -1.647 \\ -0.005 & 0.013 & -0.008 \\ -1.064 & 1.847 & -0.957 \\ 0.011 & -0.359 & 0.348 \\ 0.046 & -1.274 & 0.923 \\ -0.655 & -1.804 & 2.459 \\ -0.959 & -2.329 & 2.540 \\ -0.241 & -0.408 & 0.649 \\ -1.223 & -2.537 & 2.333\end{array}$

Payouts/Profits

(3)

\section{Lagged Payouts / Profits}

Real Growth (-1)

\section{Real Interest Rate (-1)}

Relative Investment Price (-1)

\section{Proportion of Intangibles in Investment}

\section{Profit Growth (-1)}

\# Observations

$\mathrm{R}^{\wedge} 2$

SER

DW Stat

Note: All regressions include an unreported constant. Red bold indicates significance at the 10 percent level.

T-statistics reported under coefficients 
Table 3b: Share of Profits - United States 1961 - 2006

(1)

(2)

(3)

Dependent Variable:

Investment/Profits

Payouts

$\begin{array}{lll}0.005 & 0.006 & -0.011 \\ 2.048 & 2.850 & -3.78\end{array}$

$\begin{array}{lll}0.742 & -0.796 & 0.054\end{array}$

$\begin{array}{lll}0.684 & -5.231 & 0.287\end{array}$

$\begin{array}{lll}-0.062 & 0.409 & -0.347\end{array}$

$\begin{array}{lll}-0.468 & 2.384 & -1.749\end{array}$

$2.028-0.608 \quad-1.420$

$\begin{array}{lll}4.110 & -1.010 & -1.971\end{array}$

$\begin{array}{lll}-0.003 & 0.013 & -0.010\end{array}$

$\begin{array}{lll}-0.595 & 1.815 & -1.141\end{array}$

$\begin{array}{lll}0.133 & -0.439 & 0.306\end{array}$

$\begin{array}{lll}0.593 & -1.837 & 0.974\end{array}$

$\begin{array}{lll}-0.637 & -2.102 & 2.739\end{array}$

$\begin{array}{lll}-1.010 & -3.010 & 3.619\end{array}$

$\begin{array}{lll}-0.256 & -0.410 & 0.666\end{array}$

$-1.192$

$-2.377$

2.246

\# Observations

$\begin{array}{rr}46 & 46 \\ 0.71 & 0.76 \\ 0.088 & 0.050 \\ 2.07 & 2.22\end{array}$

46
0.73
0.063
2.61

DW Stat

2.07

2.22

Note: All regressions include an unreported constant. Red bold indicates significance at the 10 percent level.

T-statistics reported under coefficients 
Table 3c: Share of Profits- United States 1961 - 2013

(1)

(2)

Dependent Variable:

Investment/

Time Trend

Lagged Investment/Profits

inger.

Pafits Payouts

Profits

(3)

$\begin{array}{lll}0.004 & 0.003 & -0.008 \\ 2.061 & 1.617 & -2.951\end{array}$

$\begin{array}{lll}0.748 & -0.690 & -0.058\end{array}$

$\begin{array}{lll}5.945 & -5.802 & -0.393\end{array}$

Lagged Payouts / Profits

0.001

0.274

$-0.275$

0.016

1.830

$-1.811$

Real Growth (-1)

1.693

$-0.108$

$-1.585$

4.726

$-0.173$

$-2.361$

Real Interest Rate (-1)

$-0.001$

0.021

$-0.020$

$-0.208$

3.177

$-2.392$

$-0.007$

$-0.688$

0.694

$-0.035$

$-2.149$

1.955

Proportion of Intangibles in Investment

$-0.962$

$-2.366$

3.328

$-1.920$

$-2.660$

3.598

Profit Growth (-1)

$-0.189$

$-0.201$

0.390

1.380

\# Observations

53

$-1.002$

0.79

53

0.71

0.046

0.76

0.070

SER

2.02

1.76

2.07

Note: All regressions include an unreported constant. Red bold indicates significance at the 10 percent level.

T-statistics reported under coefficients 
Table 4a: Panel Regression - Ratios to GDP - 1960-2001

(1)

(2)

(3)

Dependent Variable:

Investment/GDP

Payouts/GDP
0.000

Time Trend

Lagged Dependent

0.001

3.313

0.656

10.323

0.168

6.184

0.000

$-0.868$

$-0.002$

$-0.180$

$-0.001$

$-2.820$

0.003

0.390

$-0.001$

$-1.862$

127

0.96

0.005

1.75

$\Delta$ Net Financial Assets/GDP

$-0.245 \quad-2.606$

0.075

0.275

4.210

$-0.313$

$-2.800$

0.001

0.558

$-0.069$

$-1.283$

0.001

0.478

0.130

3.406

0.003

1.297

\# Observations

DW Stat

0.78

2.50

Note: All regressions include an unreported constant and country fixed effects.

Red bold indicates significance at the 10 percent level. T-statistics reported under coefficients 
Table 4b: Panel Regression - Ratios to GDP - 1960-2006

(1)

(2)

(3)

Dependent Variable:

Investment/GDP Payouts

Time Trend

Lagged Dependent

$\begin{array}{rrr}0.000 & 0.000 & -0.002 \\ 2.484 & 0.385 & -3.193 \\ 0.699 & 0.129 & 0.305 \\ 12.829 & 2.046 & 5.108 \\ 0.176 & 0.082 & -0.280 \\ 6.501 & 0.876 & -2.757 \\ 0.000 & 0.000 & 0.000 \\ 0.246 & 0.397 & 0.230 \\ 0.000 & 0.002 & -0.074 \\ -0.004 & 0.037 & -1.545 \\ -0.001 & 0.001 & 0.000 \\ -2.457 & 0.596 & 0.352 \\ 0.002 & -0.030 & 0.112 \\ 0.260 & -0.992 & 3.463 \\ 0.000 & 0.002 & 0.005 \\ -0.693 & 1.242 & 3.510\end{array}$

\# Observations

157

125

125

$\mathrm{R}^{\wedge} 2$

0.95

0.83

0.73

SER

0.004

0.028

0.033

DW Stat

1.70

2.49

2.40

Note: All regressions include an unreported constant and country fixed effects.

Red bold indicates significance at the 10 percent level. T-statistics reported under coefficients 
Table 4c: Panel Regression - Ratios to GDP - 1960-2013

(1)

(2)

Dependent Variable:

Investment/GDP Payou

(3)

Time Trend

Lagged Dependent

1.697

0.000

$\Delta$ Net Financial Assets/GDP

0.756

$-0.002$

0.758

0.181

$-3.862$

16.727

3.235

0.332

0.123

0.131

6.007

Real Growth (-1)

5.288

2.036

$-0.313$

Real Interest Rate (-1)

0.000

0.000

$-4.337$

1.037

$-0.365$

0.000

$-0.015$

$-0.005$

$-0.126$

$-1.596$

$-0.146$

$-0.056$

$-0.001$

0.001

$-1.473$

$-2.981$

0.653

0.001

0.011

$-0.006$

0.718

0.062

2.268

0.000

$-0.232$

0.006

$-0.663$

1.391

5.215

\# Observations

196

164

164

$\mathrm{R}^{\wedge} 2$

0.94

0.84

0.71

SER

0.006

0.015

0.017

DW Stat

1.89

2.31

2.25

Note: All regressions include an unreported constant and country fixed effects.

Red bold indicates significance at the 10 percent level. T-statistics reported under coefficients 
Table 5a: Panel Regression - Share of After-Tax Profits - 1960-2001

(1)

(2)

(3)

Dependent Variable:

Investment/Profits

Payouts/Profits $\Delta$ Net Financial Assets/Profits

Time Trend

Lagged Investment/Profits

0.008

$-0.003$

2.887

$-0.586$

$-0.004$

0.728

0.133

$-0.765$

10.395

0.877

$-0.859$

0.046

0.117

$-5.676$

Lagged Payouts / Profits

1.312

1.561

$-0.162$

Real Growth (-1)

2.052

0.833

$-2.173$

5.968

1.122

$-2.879$

$-0.008$

0.012

$-3.901$

Real Interest Rate (-1)

Relative Investment Price (-1)

$-2.125$

1.423

$-0.004$

0.194

0.009

$-0.430$

1.185

0.025

$-0.193$

Proportion of Intangibles in Investment

$-0.005$

0.008

$-0.540$

$-1.258$

0.829

$-0.002$

$-0.197$

$-0.179$

$-0.233$

$-1.418$

$-0.596$

0.379

$-0.017$

0.026

1.270

$-2.056$

1.452

$-0.494$

\# Observations

$\mathrm{R}^{\wedge} 2$

95
0.93
0.055
1.69

95

0.75

0.119

2.63

95

0.78

0.119

DW Stat

1.69

2.63

Note: All regressions include an unreported constant and country fixed effects.

Red bold indicates significance at the 10 percent level. T-statistics reported under coefficients 
Table 5b: Panel Regression - Share of After-Tax Profits - 1960-2006

(1)

(2)

(3)

Dependent Variable:

Investment/Profits

Payouts/Profits $\Delta$ Net Financial Assets/Profits

Time Trend

Lagged Investment/Profits

\begin{tabular}{rrr}
\hline 0.005 & 0.002 & -0.007 \\
2.130 & 0.500 & -1.597 \\
0.816 & 0.012 & -0.827 \\
14.771 & 0.107 & -7.547 \\
0.015 & 0.154 & -0.173 \\
0.471 & 2.410 & -2.690 \\
2.118 & 0.718 & -2.844 \\
6.532 & 1.123 & -4.415 \\
-0.004 & 0.003 & 0.000 \\
-1.084 & 0.495 & 0.068 \\
0.188 & 0.011 & -0.219 \\
1.236 & 0.035 & -0.714 \\
-0.003 & 0.004 & -0.001 \\
-0.839 & 0.513 & -0.145 \\
-0.048 & -0.304 & 0.349 \\
-0.418 & -1.338 & 1.524 \\
-0.007 & 0.009 & -0.001 \\
-1.350 & 0.779 & -0.091 \\
& & \\
125 & 125 & 125 \\
0.93 & 0.79 & 0.79 \\
0.055 & 0.108 & 0.108 \\
1.75 & 2.49 & 2.49
\end{tabular}

Lagged Payouts / Profits

Real Growth (-1)

Real Interest Rate (-1)

Relative Investment Price (-1)

Note: All regressions include an unreported constant and country fixed effects.

Red bold indicates significance at the 10 percent level. T-statistics reported under coefficients 
Table 5c: Panel Regression - Share of After-Tax Profits - 1960-2013

(1)

(2)

(3)

Dependent Variable:

Investment/Profits

Payouts/Profits $\Delta$ Net Financial Assets/Profits

Time Trend

Lagged Investment/Profits

\begin{tabular}{rrr}
\hline 0.004 & 0.004 & -0.009 \\
2.882 & 1.395 & -2.778 \\
0.814 & 0.032 & -0.845 \\
17.420 & 0.362 & -8.892 \\
-0.003 & 0.181 & -0.182 \\
-0.109 & 3.173 & -3.021 \\
1.474 & 0.869 & -2.343 \\
6.517 & 2.003 & -5.103 \\
-0.002 & -0.001 & 0.003 \\
-0.547 & -0.184 & 0.458 \\
0.141 & 0.043 & -0.204 \\
1.206 & 0.189 & -0.842 \\
-0.004 & 0.003 & 0.001 \\
-1.428 & 0.499 & 0.182 \\
0.033 & -0.082 & 0.047 \\
0.350 & -0.457 & 0.245 \\
-0.009 & 0.004 & 0.005 \\
-2.296 & 0.510 & 0.682 \\
& & \\
164 & 164 & 164 \\
0.93 & 0.80 & 0.76 \\
0.054 & 0.103 & 0.110 \\
1.88 & 2.32 & 2.30
\end{tabular}

Lagged Payouts / Profits

Real Growth (-1)

Real Interest Rate (-1)

Relative Investment Price (-1)

Proportion of Intangibles in Investment

Profit Growth (-1)

Over 65 Population Ratio

Note: All regressions include an unreported constant and country fixed effects.

Red bold indicates significance at the 10 percent level. T-statistics reported under coefficients 


\section{Appendix A: Data Description}

Table A.1: Sample Period for Non-Financial Corporate Data

\begin{tabular}{|c|c|c|c|}
\hline Country & Source & Start Year & $\begin{array}{l}\text { End } \\
\text { Year }\end{array}$ \\
\hline France & National Accounts & 1980 & 2013 \\
\hline Germany & National Accounts & 1980 & 2012 \\
\hline Italy & National Accounts & 1990 & 2012 \\
\hline Japan & National Accounts & 1980 & 2012 \\
\hline U.K. & National Accounts & 1988 & 2013 \\
\hline U.S. & National Accounts & 1960 & 2013 \\
\hline Austria & OECD & 1995 & 2011 \\
\hline Belgium & OECD & 1995 & 2011 \\
\hline Czech Republic & OECD & 1993 & 2011 \\
\hline Denmark & OECD & 1995 & 2011 \\
\hline Estonia & OECD & 1995 & 2011 \\
\hline Finland & OECD & 1980 & 2011 \\
\hline France & OECD & 1980 & 2011 \\
\hline Germany & OECD & 1995 & 2011 \\
\hline Greece & OECD & 2005 & 2011 \\
\hline Hungary & OECD & 1995 & 2011 \\
\hline Ireland & OECD & 2002 & 2011 \\
\hline Italy & OECD & 1990 & 2012 \\
\hline Japan & OECD & 2001 & 2011 \\
\hline Korea & OECD & 1980 & 2010 \\
\hline Luxembourg & OECD & 2006 & 2011 \\
\hline Mexico & OECD & 2003 & 2011 \\
\hline Netherlands & OECD & 1990 & 2011 \\
\hline Norway & OECD & 1980 & 2012 \\
\hline Poland & OECD & 1995 & 2011 \\
\hline Portugal & OECD & 1995 & 2012 \\
\hline Russia & OECD & 2002 & 2010 \\
\hline Slovak Republic & OECD & 1995 & 2011 \\
\hline Slovenia & OECD & 1995 & 2011 \\
\hline South Africa & OECD & 1995 & 2012 \\
\hline Spain & OECD & 2000 & 2011 \\
\hline Sweden & OECD & 1995 & 2012 \\
\hline Switzerland & OECD & 1995 & 2010 \\
\hline U.K. & OECD & 1990 & 2011 \\
\hline U.S. & OECD & 1998 & 2011 \\
\hline
\end{tabular}




\section{Data Sources and Descriptions:}

Investment, Profits, Net Dividends, Equity Buybacks: For the G6 the data is taken from national Integrated Macroeconomic Accounts by Institutional Sector. All data is for the non-financial corporate sector.

- Investment is defined as gross capital formation.

- As described in the text, profits are defined as the gross operating surplus less the combination of net interest payments, rent, net other payments, and taxes.

- Net dividends are the distributed payments of corporations less the distributed income of corporations.

- Equity flows is the net incurrence of equity liabilities.

Relative Investment Price: The ratio of the price deflator for gross fixed investment to the price deflator for GDP. When available, the investment deflator for investment by non-financial corporations, or some variation along those lines, was used. Japan = Business Fixed Investment in Non-Residential and Equipment. France $=$ Non-Financial Corporate Fixed Investment.

Interest Rates: Long rates were generally 10-year sovereign bond yields, with the exception of Japan, where the 9-year yield was used. In constructing real rates, the long nominal rate was deflated by contemporaneous annual change in the GDP deflator.

Intangible Investment: As reported by the OECD Investment by Asset. Intangible fixed assets as a percent of gross fixed capital formation.

Over 65 Population Ratio: As reported in the World Bank's World Development Indicators. 